\title{
Main Aspects of the Reception and Conveyance of Irony in the Earliest English Versions of Celestina ${ }^{1}$
}

\author{
$M^{a}$ Ángeles Ruiz Moneva \\ Universidad de Zaragoza
}

\section{Introduction}

Celestina - in its two different versions, the Comedia (Rojas, 1499) and the Tragicomedia (Rojas, ca.1502) — stands for one of the masterpieces of Spanish literature that mark the transition between the end of the Middle Ages and the birth of the Renaissance. Criticism has always acknowledged the important role played by irony in the unfolding of the plot. It has recently drawn attention to the fact that irony is much more than a mere stylistic device in the work: rather, it plays an important structural role in Celestina, so that it helps to harmonise the relationship between the comic and the tragic aspects of the complex plots and subplots that contribute to the unfolding of the action.

As for the English translations that will be analysed, the following points are worth considering. To begin with, our study has focused upon the three earliest extant versions of the work. As a matter of fact, after the last one (Stevens, 1707), readers will have to wait until the second half of the twentieth century to find new English translations of the Tragicomedia. Besides, only one of the versions analysed may be regarded as a translation of the Spanish work, strictly speaking. This does not mean that the other two versions lack importance: in fact, criticism (Rosenbach, 1903) has pointed at the Interlude of Calisto and Melebea (Rastell, 1525) as one of

1.- Thanks are due to those referees that read and assessed a previous version of the paper for their suggestions and comments. 
the earliest -if not the very first one- dramatic works written in English that present us with real characters, that is, characters who stand for actual human beings, and not just symbols, as was the common tendency of coetaneous morality plays. Thus, those that we find in Calisto and Melebea are rounded, developed characters who eventually confront inner conflicts: for instance, Melebea —as she is called in the Interlude - has to decide between passion and sticking to the moral principles upheld by the old society; or Pármeno debates between the loyalty owed to his master Calisto or the "opportunities» promised by Celestina. ${ }^{2}$

It must not be overlooked that these English versions of Rojas's work were rendered in a moment when translations acquired a capital importance in Elizabethan culture (Randall, 1963/1998; Brault, 1960; Brooke and Shaaber 1948/1967). It was generally felt that the contact of the English language and culture with other classical as well as vernacular languages and literatures should improve it. Thus, Rastell himself seemed to have subscribed such a view: "(...) our vulgare Englysh tong [has been] marauellously amended and augmentyd by reason that dyuers famous clertkis and lerned men had translate[d] (...)» (Quoted by Richard F. Jones, 1953: 88, apud Randall 1963/1998: 27).

On the whole, the diffusion of Celestina in Britain as well as in the rest of Europe has to be set against the context of the introduction of the printing press (Kish, 2009). Kish has also dwelled on the appeal of a work like Rojas's for the merchant societies of contemporary European countries, such as those of the languages the work was first translated into: Italian (Ordóñez 1506); German (Wirsung, 1520, 1534), or French (anonymous version in 1527; Lavardin 1578). Besides, Kish also shows how in some countries, like the Netherlands, translations of Celestina coexisted side by side with at least eight Spanish copies of the work by the end of the sixteenth century.

Both Rastell's and Captain Stevens' works stand for "free» versions of the Spanish work. We shall see that one of the main controversies on which critics have not really reached any consensus on Rojas's Celestina has to do precisely with its genre: readers are faced with a rather lengthy prose text, essentially formed by twenty-one Acts and written in dialogue. Because of the combination of these two features, twentieth-century criticism had oscillated between approaching it as a play or else as a dialogued novel. Whichever genre we believe that Rojas's Celestina may be ascribed to, in the two versions just mentioned, we are faced with a genre shift or departure from the original (Hatim and Mason, 1990).

2.- The distinction between «flat» and «rounded» characters was first introduced by Forster (1927) (according to Brioschi and di Girolamo 1988): on the one hand, "flat characters» are schematic and constructed around a single idea or quality; on the other hand, «rounded characters» are complex and tend to evolve throughout the entire plot. Rounded characters are likely to be capable of surprising the reader on account of their reactions. 
The present essay sets out to cover the following aspects: first, the main forms of irony to be found in the original Celestina; second, a brief account of the main features of each of the earliest English versions; and third, an analysis of the main features of the conveyance of irony in the three English versions under study. It must be noted that, precisely on account of the genre shifts of the English versions from the original, we may not expect the same forms or instances of irony in Celestina, on the one hand, and in the English versions considered -in particular, Rastell's and Captain Stevens's.

In the paper, the discussion is structured as follows: in Section 2, a synthesis of the main aspects and problems raised by irony in the original work, Rojas's Celestina, will be dealt with. Even though it is difficult to deal with such a broad topic as irony in Celestina, otherwise widely-dealt by critics, we shall attempt to dwell upon those aspects that may be relevant somehow for the analysis of irony in the three earliest English versions. Section 3 covers a general introduction to these English versions of the work, focusing, in particular, upon those traits that will be reflected in the conveyance of irony in each of these texts. It also analyses the main significant aspects of the translation of irony in these versions. Finally, in Section 4 the main conclusions reached in the study will be presented.

\section{Problems Raised by Irony in Rojas's Celestina}

Celestina stands for one of the masterpieces of Spanish literature that mark the transition from Medieval times into the Renaissance. As is well known, it recounts the tragic love affair between Calisto and Melibea. It was published, however, in two different versions: first, as a Comedia of fourteen Acts, in 1499; and second, in its present form as a Tragicomedia, with twenty-one Acts, the first versions of which appeared towards the beginning of the sixteenth century.

One of the topics hotly debated by critics regarding the source text concerns its genre, and no consensus has been reached so far on whether it is a dramatic play (Lida de Malkiel 1962/70; Bataillon 1961) or a dialogued novel (Severin 1994, 1989; Deyermond 1987, 1980, 1961; Gilman 1956/74; Ménendez Pelayo 1947). Ma Eugenia Lacarra (1989) has approached Celestina as a parody of the genre of sentimental romance, being also influenced by the humanist comedy of the fifteenth century, and the poetry of courtly love.

Moreover, a central aspect that has been raised by scholars has to do with the blending of the comic and the tragic aspects which is so characteristic of the work. This affects some important aspects, such as the figure of Calisto, seen as a parody of the courtly lover, concretely, of the 
figure of Leriano of Diego de San Pedro's Cárcel de Amor (Canet 2008; Severin 1994, 1978-9; Martin, 1972).

The approach to Calisto as a parody of the courtly lover was already dealt with by June Hall Martin (1972), who thinks that Calisto fails in his very first approach to Melibea, since he misinterprets Andreas Capellanus' recommendations in his De Amore, and addresses Melibea as a mistress. The lady would have expected to be praised not just for her beauty, but also for her honesty, virtue or prudence. For Martin, Calisto is repeatedly unsuccessful as a courtly lover, which is shown by the abrupt shifts in his speech, or by his inability to obey Melibea, regardless of how sincere she may be; thus he surrenders to sexual passion and disregards her pleas for chastity. Furthermore, Martin claims that it is also ironic that Calisto comes to employ the same sort of epithets to address Celestina as he had used in his first encounter with Melibea. Her conclusion is that not only is Calisto parodic, but he comes too close to the world and style of his servants: "The parody takes on a harsher note, a more serious corrective or didactic tone» (1972:111). For her, the parody lies essentially in the "enormous gap between what Calisto is and what he pretends to be" (1972: 112-13). In the whole structure of the work, this would have a didactic value, since Calisto would turn out to be as punished as Celestina, Pármeno or Sempronio. For Martin, this is further confirmed by the fact that «the reader is never permitted to take Calisto seriously as a lover nor to feel sympathy for him» (1972: 127).

Canet (2008) goes a step further, by showing that Calisto prefers the creature over the Creator. What is more, he repeatedly adores Melibea as a goddess. This would not only be reflected in his words addressed to Sempronio, "¿Yo? Melibeo só y a Melibea adoro y en Melibea creo y a Melibea amo" (ca.1502/2000: 92), which we will comment upon when dealing with Rastell's and Mabbe's version. These three verbs, Canet argues, are not used by chance, but refer to the three main faculties of the soul.

Other aspects of the work have been shown to be best approached in terms of parody. This is the case of the names of certain characters, such as Celestina herself: "Celestina» may be thus related to adjectives such as caelestis, which is just a contradiction for a bawd (Canet, 2008). Besides, parody seems to lie at the core of the names of other minor characters, like "Pleberio»: although it seems to have etymological connections with plebe - that is, with the common people - this name is given to Melibea's father, who must have been a member of the well-to-do social classes (Russell, 1991).

Parody, as well as such a blending of the comic and the tragic, also holds for the genre of the work. It appears that for Rojas and his contemporaries a comedy not only referred to a structural aspect of dialogue, but also to the joyful elements of the plot of the work, in particular, a happy ending. As Jones notes, "Aristotle regarded Comedy as Tragic's opposite, a depar- 
ture from the mean instead of a pursuit of it. He distinguished comedy by ruling its proper study is men "worse than the average» - not worse in every way, but worse as regards the Ridiculous (tò géloion) which is a subdivision of the Ugly» (1962/68: 56; apud D. Severin, ed. 1994: 28-9).

Similarly, $M^{a}$ Eugenia Lacarra (1989) has approached Celestina as a parody of the genre of sentimental romance, being also influenced by the humanist comedy of the fifteenth century, and the poetry of courtly love. The sentimental romance will be parodied in the love of the servants and the prostitutes, mainly Sempronio and Elicia, which mirrors that of the masters, Calisto and Melibea. For Lacarra, it is not only Calisto who is a parody of the courtly lover, but also Melibea, for reasons such as the following: first, there is no reliable description of her in the work; second, the idealistic description that Calisto makes of her ("En esto veo, Melibea, la grandeza de Dios», in Act I, p.27) ${ }^{3}$ is counterbalanced by that made by the jealous prostitutes ( Santiguarme quiero de tu necedad y poco conocimiento. ¡Oh quién estoviese de gana para disputar contigo su hermosura y gentileza. ¿Gentil, gentil es Melibea?»; Elicia, in Act IX, p. 206); or third, she shows a highly contradictory attitude towards Celestina, which results in no other than the old bawd's achievements and Melibea's absolute surrender to her.

Moreover, in his 1991 edition, Peter Russell claimed that the reference to the genre of the work in the first version - that is, Comedia - stands for one of the aspects that must be read in terms of parody. ${ }^{4}$ In this sense, the term must have meant a subversion of the tragic nature of the work. Thus, Rojas, apparently taken aback, puts forward the following in the «Prólogo» of the Tragicomedia:

Otros han litigado sobre el nombre, diciendo que no se había de llamar comedia, pues acababa en tristeza, sino que se llamase tragedia. El primer autor quiso darle denominación del principio, que fue placer, y llamóla comedia. Yo, viendo estas discordias, entre estos estremos partí agora por medio la porfía, y llamela tragicomedia.

(ca.1502/2000: 20-21, my italics).

More recently, Canet (2008) has demonstrated how Rojas's Celestina subverts and parodies every classical precept of traditional poetics, in so far as many of the characters of the work have nothing to do with those

3.- Unless indicated otherwise, quotations from Celestina will be taken from the edition in Crítica, by Lobera et al., eds. (2000).

4.- «Según Rojas, el primer autor describió la obra como «comedia», dándole «denominación del principio, que fue plazer». Habla irónicamente; jamás se había intentado definir la clásica comoedia fijándose en cómo la obra en cuestión principiaba. Pero obsérvese que la observación de Rojas confirma que él veía el Acto i como obra placentera» (1991: 25, footnote 27, italics as in the original). 
of comedy. What is more, every character may use the same kind of rhetorical and persuasive language, regardless of his status, or cultural and social background. Besides, a comedy was meant to deal with lightweight matters and events, something which stands in a clear contradiction to many aspects of Celestina. Canet also demonstrates that the functions and objectives purported by most rhetorical figures used are subverted: "Pero eso sí, la mayoría de estas argumentaciones y proposiciones en la Celestina no van hacia la búsqueda de la verdad o para que el hombre sea más moral, según pedían los humanistas, sino que en su mayoría son sofismas y falacias del discurso» (2008: 101).

Irony has always been regarded as an essential aspect of the meaning of Celestina. It has often been said that Celestina is marked by a remarkable irony from beginning to end, due to the existing contrast between different worlds and world views, which interact with one another (Alcina, 1983). Thus, we find the world of masters versus the world of servants and prostitutes, the old versus the young generation; the old, established values and their devalued status, etc. A general overview of the most important critical issues and debates generated by the role of irony in the Spanish work follows.

For Gilman (1956/74), irony in Celestina is to be found at a variety of levels, including the relationship between the author and his work. This form of irony is a resource usually traced back to Cervantes' Don Quixote; however, it can already be grasped in the work, that is, between Rojas and the Tragicomedia, especially at the level of the contrast between traditional truths and spontaneous truths: «Rojas never writes according to what he considers to be a balanced or harmonious style, he imposes no control of his own on the work of art; rather he corrects and inserts from within the dialogue and according to the tú and yo who live in it» (1956/74: 44, italics as in the original). For Gilman, Celestina also anticipates Lazarillo de Tormes in the sense that irony becomes the expression of a dilemma and of a way of existence.

Nowadays, it is generally considered that the interpretation of a work or of definite passages of it as ironic is open to the reader's criteria. This means that whether a definite utterance or, at the highest level, a definite work is to be interpreted in terms of irony will ultimately be decided by the external reader. Therefore, irony ceases to be an external or objective concept, to become a relative and subjective reality. It is in this sense that for some critics, such as Gilman himself, Celestina becomes a forerunner of Cervantes, with his modern perception of irony:

(...) Rather the effect is one of irony, of simultaneous ironical vision of two kinds of truth, spontaneous and traditional, living and canonized, particular and general. And since simultaneous vision of aspects of a situation 
or object is really another way of saying perspective, it is, I believe, fair to speak of Rojas' ironical separation from his work in much the same sense that we speak of Cervantes'.

(1956: 123).

Moreover, like Cervantes' Don Quixote as well as the anonymous work Lazarillo de Tormes, Celestina is peculiar for its perspectivism, in the sense that the reader is offered various assessments and points of view. As for the verbal portraits of the different characters, the reader has access to diverse pictures of each of them, usually made by the others taking part in the action. As Gilman points out, «it is necessary to insist on this puzzling lack of fixed portraiture because it coincides with the curious decorum of $\mathrm{Ce}$ lestina, the failure to maintain a recognizable language for each personage» (1956: 56). The solution proposed by him to this dilemma is to approach characters "as they are related to each other in dialogue, and not apart from it» (1956: 57): "Thus, while we may not have 'characters' in Celestina, Rojas knows well how to manage the characterizations furnished by the dialogue» (1956: 67). Here, an exception is perhaps Pármeno, who is the one to evolve throughout the unfolding of the action in a clearest way.

For Gilman, one of the most striking sources of irony in Celestina is precisely the knowledge that characters have of themselves, a knowledge which is acquired through the different dialogues of the work: "The irony resides, of course, in the fact that this is a dialogic consciousness - an awareness irretrievably linked to speech in its course - and so unavailing for inner salvation or willed redirection of the self» (1956/74: 196). Moreover, for Gilman irony is also created in Celestina through the peculiar structure of the work, which he sees organised from top to bottom in whole units (e.g., acts) with smaller parts. For this reason, Gilman finds that irony in Celestina can be perceived without the audience's intervention. ${ }^{5}$ In this way, the most important factor is the reader's ability to infer the ironic meaning intended in a certain context, and it seems that this irony becomes the more subtle and interesting, the less explicitly marked it is in the text.

For Lida de Malkiel (1962/70), the distinctive trait of irony in Celestina is the pre-eminence of the tragic or Sophoclean variety, which may be manifested as either verbal or situational, and which is based upon the superior knowledge of the audience if contrasted to that of the characters. As we shall see, dramatic irony is fully present in Celestina in both the dialogues between the lovers, and in those taking place between masters and servants. It is the reader's awareness of the ironic cues present throughout the text that will offer the key to the unity of the work: "Pero para el lector

5.- «By means of the act, Rojas exercises artistic control of presentation and effect from without and, at the same time, avoids any sort of direct intervention. He can even communicate irony structurally and so without the need of audience participation» (1956/74: 117). 
que, a diferencia de los personajes conoce la verdad en cada aspecto e instante del drama y está al tanto de su asunto entero, presenta además otro sentido, ligado a la esencia de la obra y, en particular, a las circunstancias trágicas de su desenlace» (1962/70: 250). It may be remembered here how the whole work is overloaded with plentiful omens and allusions to the destiny which awaits the characters, which become even more obvious if the work is read more than once. On other occasions, characters become unaware victims of their own unintended ironies, like Sempronio's pride in Elicia's loyalty, when all but he know him to be in the wrong. This shows how situational and dramatic irony, and perhaps even verbal irony, may be independent of the speaker's will or intention. Another variety of this kind of irony which is indifferent to speakers' intentions is what Lida defines as "... el irónico contraste entre el cálculo humano y el encadenamiento fatal de los hechos, que burla su fútil esfuerzo» (1962/70: 255). Thus, Celestina's endeavours to foster the friendship of Calisto's servants, Pármeno and Sempronio, will bring about her own death.

Lida also shows how another aspect of irony in Celestina is the subversion of traditionally established values, and, what is more, the carefulness of the servants to keep up appearances ("Que no te sienta la tierra» —an expression repeated by different characters, servants or prostitutes, in several passages of the work, such as Act XI, p.231 or Act XVII, p. 304)-, in contrast to the carelessness of the honourable masters. This can be approached neither in verbal or situational terms, but needs to be set against the whole of assumed values which must have constituted the author's contemporary views on this topic, which can only be perceived by readers if they have contextual access to this encyclopaedic knowledge, as we will try to demonstrate below.

The genre of the Spanish work has always been a hotly debated issue among scholars and critics. In this sense, Dorothy Severin (1994: 43) will say that irony helps to link both comedy and tragedy in Celestina. Therefore, irony will have an important structural role. Authors such as Himmelblau (1968) or Lida de Malkiel (1962/70) and Fraker (1990) have reached similar conclusions regarding this point.

Nevertheless, Severin $(1994,1989)$ emphasises that twentieth-century criticism has tended to overstress the tragic aspects of the work, to the detriment of its comic and humorous facets: «(...) El lector no debe olvidar que tal y como se retrata y ejemplifica la naturaleza humana en el libro de $\mathrm{Ce}$ lestina, ésta resulta ser esencialmente dual, tragicómica» (1994: 43). Moreover, this blending of the comic and the tragic is another of the aspects that makes Celestina a fully modern work, as already noted by Glicksberg:

The modern ironist, though he has no desire to see men suffer, is aware that the human condition is beyond remedy. His irony functions as the expression of a nihil- 
istic Weltanschauung. If the object of satiric laughter is to abolish evil, the laughter of irony is designed to fuse the elements of comedy and tragedy.

(1969: 22, my bold; italics as in the original).

Another trait noted by Lida de Malkiel, which also underlies the overall, comprehensive study of irony in the work carried out by Ayllón (1984), is that irony in Celestina is best approached as a perspective on the action superimposed by the author, Fernando de Rojas. This implies that characters are many times unaware of the consequences of their words and their actions. Therefore, for Lida, one of the main sources of irony in Celestina is precisely "the ironic incompatibility between the meaning which characters give to the action and the meaning it holds for the author and readers» (1961: 56-57).

In this sense, other studies devoted to the issue of irony in Celestina have made it clear how important it is for the accurate interpretation of irony by the reader to correctly infer the author's intended meaning. This is the case of Katherine Kayser Philips, who refers to the importance of irony as an index of the author's perspective on the facts he is referring or witnessing in the development of events: "One must keep in mind that irony is not an element in something but a perspective on it. It is a perspective held by the author as a mode of conception in La Celestina, leading to the organic unity of the work» (1974: 470).

The ironic meaning in Celestina has led critics to insist upon its modern status. Thus, at the end of the seventies, Esperanza Gurza (1977) approached Celestina from an existentialist perspective and concluded that it is a work overflowing with paradox, ambiguity, tension and irony. She coincides with many authors in that irony is a crucial trait of modern literature, which enables the audience to enjoy a much wider scope of knowledge than that of characters, and which needs the latter to make the work fully significant. Like many contemporary authors, she approaches irony in terms of attitude: "La ironía es una actitud, una visión total de la creación y de la marcha irremediable de la misma» (1977: 307). She also draws attention to the importance of the reader, who ultimate endows the work with significance, and who is the final and defining agent to determine whether something is to be interpreted as ironic or not, which is a key feature of the modernity of the work.

In Celestina characters are made to appear free to choose about their destinies. It also seems that everything, every effect, responds to a clear and explainable reason. However, there is a force, illogical and irrational, which lies at the base, a force which characters are unaware of, but which nevertheless will decide their ultimate and tragic destinies. For Gurza, this also accounts for the sympathy which the modern reader feels towards the protagonists of this drama, and explains why he can share Pleberio's final desolate solitude 
El personaje moderno se encuentra, como Pleberio, abrumado por un mundo que está más allá de su comprensión. (...) Su gran pregunta, que deja entrever todo el pesimismo existencial de Celestina, es la misma del ironista metafísico de si la vida merece la pena vivirse, cuando toda esperanza nos ha sido quitada.

(1977: 312, 315).

In what is still today one of the most complete studies on irony in $\mathrm{Ce}$ lestina, and is regarded as a classic on this topic, Ayllón (1984) carries out a highly exhaustive analysis both of ironic utterances as well as situations to be found in the work. These may be of a variety of types. For Ayllón, Celestina is characterised both by an ironic structure and by the ironic perspective of the author, the latter being superimposed upon the action. His study has led us into a classification of the most important forms of irony that can be found in the work and which are as follows: anticipatory irony and foreshadowing; retrospective irony; dramatic irony; tragic irony or irony of fate; comic irony; irony linked to ideology, in particular, to the subversion of traditionally upheld values; and finall, deceiving by telling the truth. A study of the corpus made up by the occurrence of each of these forms of irony throughout the work has allowed us to characterise them. A brief summary of the main features of these forms of irony follows.

To begin with, it is thanks to the study carried out by Kayser Philips (1974) that criticism has drawn on many of the utterances made by practically all of the important characters, which refer to the tragic dénouement of the work. Characters cannot possibly be aware of the ultimate consequences of their words. In this sense, this resource, which Kayser Philips (1974) has termed as foreshadowing, may be approached as a particular form of dramatic irony, in so far as it occurs regardless of the will and intention of the speaker, who cannot possibly be aware of the full implications of his words.

In contrast to foreshadowing, in the work we have also traced instances of retrospective irony. These will occur whenever certain utterances that may not have been intended by the speaker as ironic in the immediate context may be denied or contradicted later. Otherwise, they have implications that had not been intended by the speaker at the moment of uttering them. It may also concern the thoughts of a character regarding previous actions. It may be either verbal or situational. In the work, one of the clearest concerns Celestina's endeavour to foster the friendship between Pármeno and Sempronio which eventually will result in her own death at the hands of the two servants. As will be seen next, it is also a supreme instance of tragic irony. Another instance of retrospective irony is Celestina monologue at the beginning of Act v, when we see her exultant and happy about her success in her interview with Melibea. This 
contrasts with her own previous monologue at the beginning of Act IV, where we had listened to a much more fearful Celestina:

Celestina: Agora que voy sola, quiero mirar bien lo que Sempronio ha temido deste mi camino, porque aquellas cosas que bien no son pensadas, aunque algunas veces hayan buen fin, comúnmente crían desvariados efectos. Assí que la mucha especulación nunca carece de buen fruto. Que, aunque yo he disimulado con él, podría ser que, si me sintiesen en estos pasos de parte de Melibea, que no pagase con pena que menor fuese que la vida; o muy amenguada quedase, cuando matar no me quisiesen, manteándome o azotándome cruelmente.

(Act IV, p. 111)

Celestina: $¡$ Oh rigurosos trances! $¡ \mathrm{Oh}$ cuerda osadía! $¡ \mathrm{Oh}$ gran sufrimiento! Y qué tan cercana estuve de la muerte, si mi mucha astucia no rigera con el tiempo las velas de la petición! ¡Oh amenazas de doncella brava! ¡Oh ayrada donzella! ¡Oh diablo a quien yo conjuré, cómo compliste tu palabra en todo lo que te pedí! (...) ¡O buena fortuna, cómo ayudas a los osados y a los tímidos eres contraria! Nunca huyendo huye la muerte al cobarde! ¡ O cuántas erraran en lo que yo he acertado! (...) «La esperiencia y escarmiento haze los hombres arteros», y la vieja, como yo, que alce sus haldas al passar del vado, como maestra.

(Act v, p. 137-38, my italics).

As noted in the analysis of anticipatory irony and foreshadowing, characters are often unaware of the consequences and implications of their words. This is one of the main reasons that accounts for the importance of dramatic irony, which has been usually defined as the spectators' or external readers' awareness of certain facts which remain unknown to a certain character, and which moreover will crucially determine the latter's future or fortune.

Similarly to dramatic irony, in the case of tragic irony, the character is unaware of what may befall him or her. What may be regarded as peculiar about tragic irony is that the "hero" or "heroine» makes a mistake which will bring only disaster to him/ her (ands perhaps to others, as well). In the work, this is particularly true of the shrewd Celestina, who fails to see the implications of actions which will bring her to the grave: she fosters the friendship of Pármeno and Sempronio, and they will be closer than ever when executing her. In this sense, Celestina becomes a tragic figure who makes a fatal mistake which will be her ruin 
As we have just seen, on the whole - except for remarkable exceptions such as Severin (1994, 1989, 1978-9), Lida de Malkiel (1962/70, 1961) or Russell (1991) - twentieth-century criticism tended to neglect the role of humour in the work. And still, there are comic aspects, even though, as Severin $(1994,1989)$ has pointed out, there is much cruelty in the humour found in Rojas's Celestina.

Irony in Celestina also has a thematic and ideological message, so that an important aspect of the Tragicomedia de Calisto y Melibea concerns the subversion of the moral and social values that would be traditionally accepted and upheld as the "correct» ones. The work presents us with characters that belong to the upper classes of society, despite which they are absolutely careless and neglect in every possible way the values that they should defend: honesty, honour, prudence, or wisdom. Significantl , however, it is servants and prostitutes, representatives of the lower social classes, that will show more concern about honour: thus, servants will ask their masters "que no te sienta la tierra" (for instance, Sempronio to Calisto in Act XI, p. 231; or Areúsa to Sosia in Act XVII, p. 304). Likewise, we will listen to a proud Areúsa who declares the importance of the nobility of the heart, and not so much of blood or social status: «Procure de ser cada uno bueno por sí, y no vaya a buscar en la nobleza de sus pasados la virtud» (Act IX, p. 208).

Ayllón also draws attention to the ideological aspects of irony in $\mathrm{Ce}$ lestina, which subvert traditionally assumed values, such as the praise of honesty and the care for the public manifestations of honour: in Celestina these are only observed by the old bawd, the servants and prostitutes, and which are nevertheless totally neglected by the careless members of the nobility, from the lovers to those who should have been their "guardians». The social scope of the irony of Celestina, which will be reflected in the work by the treatment of the different characters, was also noted by authors such as Rodríguez Puértolas $(1976,1972)$. In any case, another of the sources of irony in Celestina is precisely the notion of honour that characters such as Celestina or the prostitutes and servants have: for instance, Celestina sees herself most honourable when she used to have the greatest number of whores at her home working for her, which clearly subverts the traditional concepts and assumptions about honour.

Finally, we have been able to trace instances of a peculiarly important form of irony to be found in Spanish Renaissance and Baroque drama, namely, the form termed as "deceiving by telling the truth». In contrast to traditional definitions of irony - which are generally based on some kind of discrepancy between what is «said» and what is «meant» -, characters may actually mean what they say and still be ironic, mainly by intending to cheat their interlocutors. Many times this form of irony will be based not only on verbal aspects, but also on situational factors. A 
clear instance is Elicia's concealing Crito, on Sempronio's arrival, when she does tell him that there is another of her lover's upstairs:

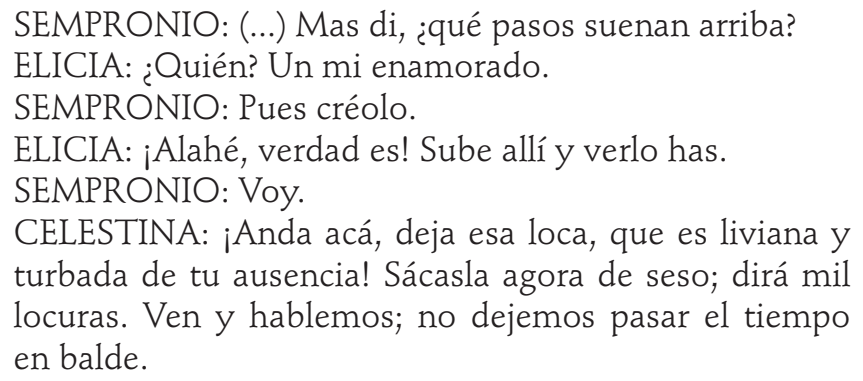

On the whole, most of these forms express the author's ironic and deeply pessimistic perspective, manifested in structure, sources, topics and characters. Irony is an essential component of the work, especially in its anticipatory and dramatic varieties, without which the unfolding cannot be fully understood: this is especially the case for what affects the dénouement of the work, and of the different characters which is foreshadowed -in the sense described above by Kayser Philips (1974). Hence, the author's ironic perspective is a further layer of the communicative levels to be found in the work, which is superimposed upon the actual unfolding of events, manifested through characters' interactions. In our view, this is a further aspect of the "modernity" of the work, in so far as it relates irony to the conveyance of a certain attitude.

A different approach to the study of irony in Celestina has taken into consideration its connections with rhetoric (Snow, 1996). For this author, an understanding of the rhetorical practices that are being used, in the context of the late fifteenth century, may bring about an enriching interpretation of Celestina. Such rhetorical design has both structural and argumentative roles. For Snow, it is the rhetorical design that makes the dialogic action unfold in the work. Besides, it creates interesting aspects of accessibility both to characters and to the external reader. Many times, in superior instances of dramatic irony, a certain character is unaware of the consequences even of his own words. Moreover, it is not infrequent to find characters speaking in asides, so that their interlocutors miss many of the meanings initially intended. This depends crucially on the different "communities of interests» that characters keep on plotting as the action unfolds. Such a rhetorical design also allows the external reader to enjoy a much wider perspective than the one which the different characters have access to.

To sum up the main aspects of the discussion sketched above, it may be said that studies about irony in Celestina have revealed that such a resource can show the multiple layers of interpretation which are possible in the work. This also means that there is no reading to be regarded as 
the "correct» one; rather, many potentialities are hinted at, which may eventually be completed or fulfilled by different readers' inferences. The door is left open for the latter to choose, even though, as noted by Gilman (1956/74), the main site for irony in Celestina lies in the dialogues amongst the different characters. Be as it may, the ironic implications of many of the utterances by some characters in their monologues should not be overlooked. In any of those cases, readers are privileged with a knowledge superior to that of all the characters in the play. As seen elsewhere, one of the most tragic and dramatic manifestations of irony in the work is that characters fail to be aware of the consequences of their own words and actions: thus, we hear repeatedly Celestina referring to her own death: for instance, she does so when she meets with Calisto, after her first interview with Melibea, in Act vi: "¿Con qué pagarás a la vieja que hoy ha puesto su vida al tablero por tu servicio?» (ca.1502/2000: 143). She also takes pains throughout to create bonds of friendship between the two servants, Pármeno and Sempronio. However, the one-time comrades will murder her when she refuses to share with them what she has obtained from Calisto. Underneath the different actions of the characters, it is the author himself who marks a distance between himself and his work.

On the whole, therefore, the aspects that will be studied in the three earliest English versions of Celestina will be the following: whether there is any perspectivism leading to irony in the relationship between the author and his work in each version; whether the forms of irony about to be mentioned next are reflected in each of the English versions, and if so, how: anticipatory irony and foreshadowing; retrospective irony; irony linked to a subversion of traditionally upheld values; tragic irony; parody; or comic irony. It is our purpose to trace whether these forms of irony were reflected in versions that were heterogeneous and departed from the original - most importantly, in the case of Rastell's and Stevens'. A general introduction into each of these versions will be provided. This will be followed by an analysis of whether these forms of irony where conveyed in each version: if not, why this may have been the case; if so, how and whether they sought to achieve similar purposes and effects.

\section{Celestina in England: The Earliest Versions. Main Aspects of the Conveyance of Irony in these Works}

The influence of Rojas's Celestina upon contemporary and forthcoming literature, not only of Spain, but also of other European countries, such as Italy, France or Germany was going to be great (Rosenbach, 1903). In what follows, I shall focus upon the three earliest English versions of $\mathrm{Ce}$ lestina, namely, Rastell's Calisto and Melebea or A new Commodye in English 
in Maner of an Enterlude (ca.1525), Mabbe's The Spanish Bawd, Represented in Celestine or the Tragick-Comedie of Calisto and Melibea (1631), and Captain Stevens's The Bawd of Madrid (1707). ${ }^{6}$ The most important recurrent trait is perhaps the remarkable heterogeneity of these texts, especially Rastell's and Stevens' versions, and the genre shift from the original Spanish text. Hatim and Mason (1990) referred to phenomena like these as intertextual hybridisation, which they defined as follows: "This is when, in subtle and intricate ways, a text is shifted to another type and made to serve another purpose without completely losing at least some of the properties of the original type» (1990: 147).

In Elizabethan England, translation lacked a substantial corpus of theoretical principles, which will not be developed until Dryden (Morini, 2006). Only scattered notions in works such as prefaces or dedications are to be found. Besides, these do not seem to account for the actual translations produced. This leads Morini to conclude that we are dealing with a transitional period between medieval ideas and the new practices and methods that would eventually be imported from the Continent.

In a sense, the works under consideration illustrate the dichotomy signalled by Morini: for this author, in Medieval times translation is seen as a form of recreation, which may even involve a radical departure from the original. In contrast, the rules and methods established by the $\mathrm{Hu}-$ manists come closer to current views, which pose the translator's invisibility (Venuti 1995) and the 'fluency' of the translated text — that is, its readability as an original - as conditions for a good translation. The former would be the case of Rastell's version; the latter would be illustrated by Mabbe's translation.

In what follows, we shall focus upon the most important aspects of the conveyance of irony in each of these three works. The study will be set in the context of the most important features of each of the versions analysed. This is so since, in our view, an adequate understanding of irony can only be achieved if such a resource is contextualised in the wider panorama of the general aims and traits of the different works under consideration.

\section{John Rastell's Calisto and Melebea (ca. 1525) ${ }^{7}$}

John Rastell may be described as a typical humanist: he pursued a career in law and was also interested in the introduction of the printing

6.- Indispensable sources for the historical reception of Celestina in Western civilisation have been provided by Prof. Joseph Snow. Apart from the bibliographic issues that accompany each volume of the journal Celestinesca, Snow (1997) and Snow (1985) are worth mentioning.

7.- A more detailed account of some aspects of the contents covered in this section was carried out in two previous works on Rastell's Interlude: Ruiz Moneva, Ma A. (1998): «Inter- 
press, which was already taking place in England, thanks to the labour of other humanists such as William Caxton. He married a sister of Thomas More's and his own daughter Joan married John Heywood, who was to be regarded by critics as one of the wittiest interlude makers. A recurrent trait of his works is the theme of the rationality and justice of human society. It seems that he may have been acquainted with Rojas' work through John Heywood as well as through the influence that a Spanish humanist, Juan Luis Vives, had in England (Axton, 1979). The emphasis of the Interlude on moral standards, in contrast to the original Celestina, may have substantiated this thesis. Even authors such as Rosenbach (1903) have suggested that Rastell may have been just the printer or publisher, the work having been perhaps produced by a pupil of Vives'. More recently, Ardila (1998) argued that the influence of Vives and also of moralists such as Thomas More may account for many of the variations introduced by Rastell, which we will comment upon below. It was published without the name of the author and without the date, under the title "A new commodye in englysh in maner of an enterlude rygkt elygant \&full of craft of rethoryk/ wherein is shewd \& dyscrybyd as well the bewte $\&$ good propertes of women/ as theyn vycys \& euyll conditions/ with a morall conclusion \& exhortacyon to vertew».

Interludes became very popular in England in the fifteenth and sixteenth centuries, particularly in the decades between 1550 and 1580. Some of them are similar to other dramatic pieces, such as the Morality Play, the Mystery Play, or the psychological drama of the Elizabethans. The boundaries and differences between these plays may not always be fully clear. As pointed out by Navarro García (1981), not only does Rastell's Interlude stand for the first manifestation of Celestina in England, but the work also engages with the genuinely English tradition and preoccupations put forward by the most important manifestations of coetaneous drama.

The most important aspects of Rastell's version are heavily constrained by the genre shift undergone by the original work into the form of an interlude. An interlude, as noted by Axton (1979) - the editor of a selection of Rastell's works - is a short play, many times meant to be played between the performances of the different Acts of a longer work. This is also illustrated by the etymological meaning of the term itself. There are usually six characters, who often announce their arrivals and departures, so as to call for the audience's attention. Furthermore - as happens in Calisto and Melebea - they generally introduce themselves. These plays may be extremely varied, as pointed out by Axton, alternating grave and trivial matters, and may be typically described as 'merry'. At the same

personal communication and context accessibility in the interpretation of ironic utterances. A case study: Rastell's version of La Celestina». Revista Alicantina de Estudios Ingleses 11: 193-216; and also Ruiz Moneva, Ma A. (2001): From Rojas's "La Celestina» to Rastell's "Interlude»: Problems in the Translation of Irony. Ann Arbor, Michigan. 
time, they may contain a certain moral purpose or be allegorical. Roughly speaking, Calisto and Melebea follows most of the features of the interlude described above. In contrast to the original ${ }^{8}$, the Interlude has to be seen as a work meant primarily to be represented.

Thus, the work is not divided into Acts; only scenes would be strictly distinguishable, on the basis of the different characters participating in each. Some of the most important characters introduce themselves: namely, Melebea, Celestina, and Danio. The latter is Melebea's father, thus, the counterpart of Pleberio in Celestina. On the other hand, the rest of the characters are introduced in the process of dialogues with the former: Calisto, Sempronio, Pármeno. On the whole, this amounts to a total of six characters, as is typical of interludes.

The fewer number of characters playing in Calisto and Melebea is not only a result of the conventions of the genre. It is also a consequence of the great simplification of the plot undergone by the work: thus, there is only a main action, which has to do with Calisto's attempt to seduce Melebea, the rejection of the passionate lover by the young lady and his accounting his servant Sempronio with his problem. After being advised to consult the old Celestina and Parmeno's hopeless attempts to dissuade him from such a task, and after Celestina's interview with the young lady, it is the latter's father -Danio, in the English version - who puts an end to the whole story, by requesting his daughter to explain what has happened. Danio has had access to what has happened through a dream, and conveys also the final moral of the story, even though his tone cannot obviously reach Pleberio's desolate outcry.

Rastell's work, therefore, only makes use of very concrete aspects of the original: the Prologue has been largely compressed and rearranged, and, above all, it is spoken by Melibea, whilst she is waiting for her too insistent wooer. Also, the role of the servants is limited in so far as they either facilitate (Sempronio) or else object (Parmeno) to Calisto's love affair and the intervention of the old Celestina. There is no further subplot, and no other servants have roles in the action.

8.- During the twentieth century, there were several dramatisations of Celestina early in the century as well as in the forties. In the later part of the twentieth century, two different stage adaptations of the work in Spanish have been produced: one, by the poet Luis García Montero, which was premiered on May, 8th 1999 at the Teatro Cervantes in Alcalá de Henares (Walsh, 2000), featuring Nati Mistral as Celestina; the other, by Robert Lepage, featuring Nuria Espert as the old bawd, being the version co-produced by the «Fundación de la Comunidad Valenciana Ciudad de las Artes Escénicas». The latter was first premiered in October, 2004 in Sagunto, at the one-time iron and steel factories. Besides, a film was also produced, directed by Gerardo Vera, in 1995, with Terele Pávez as the old Celestina. Another remarkable adaptation has been an opera version by Joaquín Nin-Culmell, probably composed in the late nineteenth-fifties - and then revised several times until the nineties (Huertas, 2008)—, but first played on the stage in the Teatro de la Zarzuela in September 2008. Moreover, Joseph Snow and Arno Gimber (2007) reviewed the different opera adaptations of Celestina undertaken in the twentieth-century. 
From the point of view of the relationship to the original, Celestina, Rastell's Interlude is best described as a verse adaptation of the Spanish work, mainly written in royal stanzas, a form widely used in English Renaissance literature. Thus, Rojas's work is formed by twenty-one Acts, and it is preceded by a Letter of the Author to a Friend, several acrostic verses which were initially, in fact, the only clue to the authorship of Rojas-, a Prologue and a synthesis of the "Argumento" (Plot) of the work. Likewise, each of the Acts of the work is preceded by an "Argumento" or synthesis of the main events that are about to unfold in that same Act.

As a result of the different unfolding and denouement of the story, there will be certain forms of irony which play an important role in the Spanish original and which simply have no role in the English adaptation: thus, no traces of tragic irony or of foreshadowing may be traced, because of the happy ending of the Interlude. Some other forms, however, will rather be enhanced by certain conventions of the genre: thus, several among the main characters - most importantly, Melebea and Celestina- introduce themselves.

Whereas the action in Rojas's Celestina, strictly speaking, starts in medias res with the interview between Calisto and Melibea already taking place, in Rastell's Interlude this is preceded by a monologue by Melebea. Her words stand for the first description and access of the external audience to the figure of Calisto: this means that everything the passionate lover does will be filtered through the initial assumptions provided by Melebea. Furthermore, in a sense, this feature enhances the parodic and comic nature of Calisto:
MeLEBEA:
I know that nature hath gyvyn me bewte,
With sanguynyous compleccyon, favour and fayrenes;
The more to God ought I to do fewte
With wyll, lyfe, laud, and love of perfytnes.
I deny not but Calisto is of grete worthynes,
But what of that? For all hys high estate,
Hys desire I defy and utterly shall hate.

(1525: 70).

Therefore, the first time that readers or spectators see Calisto on the stage, they have already entertained certain assumptions regarding the way the character may behave like. Certainly, they are given the opportunity to rejoice and enjoy, on seeing these hypotheses on the nature of the courtly lover being parodied confirmed. Thus, in her previous monologue, Melebea had pointed out the following about her wooer:

MelebeA:

Wyst he now that I were present here, 
I assure you shortely he wold seke me; And without dout he dothe now inquere Whether I am gone or where I shuld be.

(1525: 71).

Indeed, the audience will see these words reflected in Calisto's behaviour on turning up on the stage. Other aspects that enhance the irony of the original text in this version are largely due to the rhymed verse in which the work is written: thus, the formal similarity may be opposed to the contradictory meanings enhanced by the propositional contents of the words used:

Calisto: (...)

For they glorify by his assuryd presens

And I in torment because of your absens.

(...)

MelebeA:

And I promise the, were thou art present, Whyle I lyff, by my wyll I wyll be absent.

(1525: 71, my italics).

On the whole, the author of the Interlude had to synthesise the action and had less space to let characters express themselves and act. As noted by Purcell, «the length of the Celestina allows for more gradual psychological development» (1967: 6). In a sense, this is compensated for by the feature of the interlude as a genre that makes them introduce themselves. But on the whole, characters in the Interlude appear much plainer than her counterparts in Rojas' work.

Other reasons that account for some of the changes to be found in the Interlude may be connected with such aspects as the following: the adaptation of a prose work into a verse, rhymed form; the adapter's wish to mitigate and temper certain exaggerations of the original (Purcell, 1967), in particular, those elements having to do with aspects of bawdy and the most blasphemous elements of the original. When coping with Mabbe's translation, we shall find that the treatment of religious elements becomes a significant challenge for the translator. Some other topics that were omitted by Rastell could have been connected with unpleasant or else too explicit language. Some other times, the introduction of religious remarks are found in characters that would not be expected to behave that way. Thus, there is no reflection in the Interlude of the complex relationship that Celestina holds with the Church: as noted above, perhaps because of the much plainer character she has become, and also because of the absence of any social criticism of institutions such as the Church. Yet, Celestina makes a reference to her work — «I am sought and send 
fore as a woman universall» (1525: 78)-, whilst at the same time the very first words that she utters on introducing herself to the audience come as a sort of benediction. As a result, Celestina is above all perceived as a rather comic character. Little is left or her shrewdness and many other aspects of her psychological complexity in the Spanish work:

\section{Celestina: \\ (...) \\ Now the blessyng that Our Lady gave her sone, That same blessing I gyve now to you all!}

Other important differences (Geritz 1980, 1979) concern the different approach to the passion of love, the subordination of characters in the English version to the moral lesson whose transmission is mostly aimed at, and the stress on morality - which almost turns it into propaganda, being influenced by Humanists such as Thomas More, Erasmus or Juan Luis Vives. The latter may have contributed decisively to the introduction of Celestina in England. According to scholars such as Martínez Lacalle (1972), this is reflected in the allusions to the Virgin Mary that appear in the English work, or the final admonition by Melebea's father to parents in general.

But still the influence of Celestina is important, in so far as the Interlude introduces features which were new to the British literary panorama of the time (Purcell, 1967; Schelling, 1923; Rosenbach, 1903). In particular, Schelling highlights three important contributions: a clear depiction and individuation of characters; very lively dialogues; and finall , a dramatic and technical construction far beyond contemporary English authors. Rosenbach (1903) had also noted that, in contrast to morality plays, the characters of the Interlude are not allegorical or philosophical abstractions, but characters "in the flesh». He even hypothesises that perhaps Rastell's Interlude might have been the very first English play to present us with real, human characters. This is Rosenbach's view, writing in 1903. In a sense, some of the characters of Celestina, and also of Rastell's Interlude, such as the old bawd herself or Pármeno, may be regarded as well-rounded characters, in the sense put forward by authors like Forster (1927): they show some inner complexity and tend to evolve as the action unfolds. Besides, for Rosenbach, the Interlude was a work meant for the stage, whereas the original - whichever genre it is ascribed to- is above all meant to be read. This critic also provides a more general assessment of what Celestina meant for the English literary panorama of the time: he notes that Rastell's Interlude stands as "the monument of the first literary contact of England with Castile», to which it is indebted for its plot as well as its romantic setting (1903: 43). 
Rastell must have faced the problem of the conveyance of those religious and mythical allusions of the original, some of which are clearly used in an irreverent or even blasphemous manner (Navarro García 1981). In contrast to what we shall find next in Mabbe - where we shall also deal with the complexities and intricacies of the treatment of religious allusions in the different versions rendered by this author-, Rastell eventually opts for conveying almost all of them. Even so, some instances of a certain paganisation may already be found, as in Calisto's praise of Melibea as a goddess when answering his servant Sempronio:

Sempronio: Digo que nunca Dios quiera tal, que es especie de herejía lo que agora dijiste.

(...)

Calisto: ¿Mujer? ¡Oh grosero! ¡Dios, Dios!

Sempronio: ¿Y asílo crees, o burlas?

Calisto: ¿Que burlo? Por Dios la creo, por Dios la confi so, y no creo que hay otro soberano en el cielo aunque entre nosotros mora.

Sempronio: ¡Ja, ja, ja! (¿Oístes qué blasfemia? ¿Vistes qué ceguedad?)

Sempronio: Mary, syr, that is a spyce of heryse.

(...)

CALISTO: A woman! Nay, a god of goddesses.

Sempronio: Belevyst that than?

CALISTO: Ye, and as a goddess I here confesse

And I beleve there is no such sfferayn

In hevyn though she be in yerth.

Sempronio: Peas, peas!

A woman a god? Nay, to a God a vyllayn.

Of your sayeng ye may be sory.

It is playn.

(TT: 73-74).

The fact that the aside has not been conveyed as such in Rastell's text, but has on the other hand been incorporated directly into the dialogue, makes it that Sempronio's words "Of your sayeng ye may be sory" become rather a kind of warning. What is more, Melebea is compared to a goddess, in the clearest instance of paganisation of this fragment: «A woman! Nay, a god of goddesses». This is so instead of Calisto's reference to Melibea as if she were God in Celestina: "¿Mujer? ¡O grosero! ¡Dios, Dios!». Likewise, the term «blasfemia» has been omitted by Rastell. The English version, therefore, softens the strongly irreverent words of the original. Other expressions like this utterence by Sempronio, "que 
no pensaba que había peor invención de peccado que en Sodoma» (ST: 37) have been expunged altogether.

\section{Mabbe's The Spanish Bawd, Celestine or the Tragick-Comedie of Calisto and Melibea (1631)}

As noted above, this is the only version that maintains the structure and the genre of the original work, however complex it may actually be. Mabbe was in fact a prolific translator from Spanish: thus, he also rendered versions of picaresque novels, such as Mateo Alemán's Guzmán de Alfarache, which was entitled in English as The Rogue, and which seems to have been very successful and widely-read. Other works translated by Mabbe are Cervantes' Novelas Ejemplares.

Mabbe's rendering of Celestina is very important, in so far as it remained the only extant translation of Rojas's work into English until the second half of the twentieth century. Besides, the existing contemporary translations which were produced since the decade of the fifties onwards are based on Mabbe's to a great extent. These are the following: Celestina, by Lesley B. Simpson (1955), which is a translation of the earlier Comedia, of sixteen acts; Celestina, by Mack Hendricks Singleton (1958), Phyllis Hartnoll (1959), The Spanish Bawd, by J.M. Cohen (1964) and The Spanish Bawd, by Wallace Woolsey (1969). Recently, two new translations have been published: one, by Peter Bush (2009), Vice-President of the International Federation of Translators (FIT), in Dedalus Press; another, translated by Margaret Sayers Peden (2009) and edited by Roberto González Echevarría, in Yale University Press.

Mabbe actually undertook two different translations of Rojas's Celestina, ${ }^{9}$ which have survived in different critical editions - as noted by Kathleen Kish (herself editor of a German and another Dutch translations of Celestina) in two papers $(1996,1989)$ - The first edition and translation rendered by Mabbe, probably composed towards the year 1598, was more literal, and contained notes that enhanced the didactic and moralistic values. It was the 1631 version that systematically substituted pagan elements for the original Christian motives and allusions. Martínez Lacalle (1972) edited the one from the only surviving manuscript, whereas James Fitzmaurice-Kelly (1884) and Warner Allen (1923)

9.- Joseph Snow (1997: 155) makes reference as well to a third edition of Celestina by Mabbe: "The Rogue, or the Life of Guzmán de Alfarache (...) to which is added the Tragi-Comedy of Calisto and Melibea; represented in Celestina. 3rd. ed. corrected. London: Robert Allot, 1634. BL645.1.12. La TCM [Tragicomedia] ofrecida es la de 1631, publicada por el mismo Allot». Besides, Mabbe's 1631 version was to become adapted for the stage: it was performed at the Crucible Theatre, in Sheffield, in September 1978 - as noted in the "Pregonero" section of Celestinesca 2.2 (1978) - . All this shows the relevance of Mabbe's version nowadays. 
produced two different editions taken from the early printing of Mabbe's edition. Allen (1923) also included Rastell's Interlude.

As has been noted by scholars like Allen (1923), Guardia $(1998,1971)$, Martínez Lacalle (1972), or Kish (1989), Mabbe's 1631 edition of The Spanish Bawd has peculiar, distinctive traits. Among those, one aspect stands out markedly: the treatment of religious allusions, such as God, the Church or the Christian world at large. Thus, the name of God has been replaced by words like "He», "Heaven» or "Deity", or even by mythological allusions: "Apollo», "Mars», or "Pluto». Besides, quotations from the Bible have been omitted or expurgated. Likewise, blasphemous references have been changed or removed. Several reasons have been put forward so as to account for this: thus, Houck (1939) claimed that this might have been done in order to paganise or secularise and adapt the work to the Humanist spirit of the Renaissance; Russell (1953a, b) suggested that it might have been hard for the English audience of the time to put up with the "unregenerate» language of characters who were supposed to be Christians.

Warner Allen (1923) dwells upon the importance of Mabbe's translation. He also praises Mabbe's work in so far as, in his view, it reads not as a translation, but as a genuinely English original. Some stylistic features are underlined, such as the English author's use of witty puns or play-onwords. Thus, Calisto's incredulity on hearing the promises of help made by his servant Sempronio, "Increíble cosa prometes» (Act I, p. 35), becomes "Thou speakest of matters beyond the moon. It is impossible» (1631: 5 , my italics).

In his study, Pedro Guardia $(1998,1971)$ notes that the main reasons to account for the paganisation undertaken by Mabbe in his 1631 version may have been the following: respect based on a Puritan influence; the author's purpose to satisfy his protector and sponsor T. Richardson by introducing mythological allusions instead; the weakening of praying formulae in which the name of God is involved during the Jacobean period; the author himself being a Protestant; and his possible intention to obey an Act of Parliament (1606) according to which the names of God, Christ, the Holy Spirit, the Trinity, etc., should not be uttered upon the stage. Be it as it may, for Guardia $(1998,1971)$ and Celaya and Guardia (1992), one of the most striking peculiar features of Mabbe's The Spanish Bawd is precisely the mythologisation of the text, which may have been grounded in a certain ironic purpose, in so far as it stands for some kind of subversion of traditionally upheld values.

Martínez Lacalle (1972) also believes that Mabbe's translation of the Tragicomedy must have been affected by this Act of Parliament issued on May, $27^{\text {th }}, 1606$, which was known as the Act of Abuses. This Act imposed a fine of ten pounds on "any person or persons [who] doe or shall in any Stage play, Interlude, Shewe, Maygame, or Pageant jestingly or pro- 
phanely speake or use the Holy Name of God or of Christ Jesus, or of the Holy Ghoste or of the Trinitie» (apud Martínez Lacalle 1972: 37). It is believed that Mabbe might have completed his new translation of Celestina shortly after the issue of the Act of Abuses, and that he must have altered his version with a view to avoiding the effects of censorship. He must have believed that the text would have not been accepted by the English readership. In this sense, Ardila (1998) refers to a series of remarks and annotations made by Mabbe on which he comments morally some of the blasphemous contents found in the original. Thus, the following passage of Celestina in which Calisto equates Melibea with a goddess, is not only softened in the translation, but annotated by Mabbe as "Atheist»:

Sempronio ¿Tú no eres cristiano?

Calisto: ¿Yo? Melibeo só y a Melibea adoro y en Melibea creo y a Melibea amo.

(ca.1502/2000: 92)

Sempronio: Onely I doubted of what religion your Louers are.

Calisto: I am a Melibean, I adore Melibea, I beleeue in Melibea, and I loue Melibea.

Moreover, in a further aspect of her broad, comprehensive studies devoted to the work under consideration, Dorothy Severin (1987) provided a bilingual, parallel text of both the original Rojas's Celestina -following her own edition for Alianza Editorial, completed in 1969- and Mabbe's The Spanish Bawd, in his 1631 version. As a matter of fact, she also translates two pieces of the initial paratext of Celestina which were not included by Mabbe, namely, the "Carta del autor a un su amigo", as well as the initial and final verses: The initial ones included the acrostic references to the identity of the author, "El Bachiller Fernando de Rojas». In her edition, Severin notes down the most relevant departures both from the Spanish original text as well as from the earlier translation undertaken by Mabbe (ca. 1598) and reflected in the manuscript version. At the same time, her edition of the Spanish text also distinguishes the original pieces that had already been included in the Comedia from the additions later introduced in the final versions of the Tragicomedia.

It must also be remembered that one of the facets covered by Severin in her studies on Rojas's work precisely concerns irony, which she endows with significant structural importance, in so far as it connects its tragic and comic aspects. In fact, in her introduction to her critical bilingual edition of Rojas's and Mabbe's Celestina, she notes down that "Rojas' main stylistic weapons in communicating his complex message are comedy and tragedy, bound together by irony» (1987: xiii). 
Mabbe's version is also generally characterised by the tendency to express important concepts and ideas through geminations and other doublets or even triplets. This corresponds to a recurrent tendency in the English prose at the time. These may affect crucial aspects of the meaning conveyed by the speaker: thus, some of the doublets may enhance the ironical meaning of the passage. This may have further implications, not always intended by the speaker, but which the author may have added to signal and highlight. Thus, the target text has sometimes been found to make more explicit allusions to tragedy. At other times, the insistence upon the contents of the words may possibly have resulted in a diminution of the effects of irony, a resource that is the more enjoyable the less it draws attention on itself:

Sempronio: (...) Si pasión tienes, súfrela en tu casa; no te sienta la tierra; (...).

Sempronio: (...) If you are opprest with passion, indure it at home in your owne house, that the world may not perceive it.

(1631: 126-27, my italics).

Here we hear Sempronio, who has been anything but a loyal servant -in contrast to what Calisto happens to think of him - and who must precisely be the one to remind his master about what he should and should not do on the basis of the stardards of nobility. And this is not the only case. Even the same sentence, "que no te sienta la tierra", may be found on different occasions throughout the book, as Lida de Malkiel has noted. ${ }^{10}$ But his careless unawareness prevents Calisto from paying attention to the wise advice of his servants, as well as from being able to discern Celestina's true intentions.

Apart from these distinctive aspects of Mabbe's translation of Celestina, and because of the greater formal similarity with it, we may expect forms of irony closer to those found in the Spanish original. Next, instances of some of these will be provided. In particular, we want to find out whether the peculiar traits just commented of Mabbe's style might have introduced certain interpretations and shades of meaning.

Even though instances of foreshadowing and anticipatory irony are found throughout the Spanish original, these will become more intense as we approach the denouement of the story. We have already heard Celestina

10.- According to Lida de Malkiel (1970), such words can be found, and always uttered by servants and prostitutes, in the following acts: IV, XI, XVII. Nevertheless, as this author remarks as well, a further turn of the screw is the fact that neither do the servants or the prostitutes attach to this norm: thus, just to give a representative instance, she says, Sempronio and Pármeno will die beheaded in the street after having been publicly charged with and summarily sentenced for their crime. 
referring to her own death, and therefore, not only when this is about to occur, in Act XII, shall we find doublets and references with greater explicitation and amplification in Mabbe's version. This is the case of instances such as the following:

PÁRMENo: Madre, ¿mandas que te acompañe?

Celestina: Sería quitar a un santo por poner en otro; acompáñeos Dios, que yo vieja soy; no he temor que me fuercen en la calle.

(ST: 381; Act VII).

PARMENo: Mother, will you that I waite vpon you? Shall I accompany you home?

Celestina: No mary shall you not; that were but to strip one, and cloath another; or againe, it needs not, for I am old, and therefore feare not to be forced in the streets. I am past all danger of rauishing.

ELICIA: ¿Cómo vienes tan tarde? No lo debes hacer, que eres vieja; tropezarás donde caigas y mueras.

Celestina: No temo eso, que de día me aviso por dó venga de noche, (...)

(ST: 237; Act XI).

ELICIA: How chance you come so late? It is not well done of you (being an old woman, as you are) for you may hap to stumble, where you may so fall, that it may be your death. Celestina: I feare not that (wench). For I consult with my selfe in the day, which way I shall goe in the night; (...)

(1631: 130-31).

In the dialogue between Parmeno and Celestina, we can see how once more Mabbe has opted for not reflecting the religious allusion to God, which in this case he has omitted altogether. In contrast, the reference to sexual violence has been expanded. More directly connected with foreshadowing, in the conversation taking place between Celestina and Elicia, we see how it is precisely those aspects that are directly connected with Celestina's death that are amplified by Mabbe. This must have been due to his intention to enhance and emphasise what is important for the development of the action.

Mabbe also reflects those instances of irony that we have termed as retrospective irony. In a sense, foreshadowing and retrospective irony may be best approached as complementary, as Katherine Kayser Philips already noted: 
As one re-reads and studies any classic work of literature, his enjoyment and understanding is enhanced by foreknowledge: in the case of La Celestina, his foreknowledge is informed with retrospective irony as he studies the artistic means - especially the ironic foreshadowing - by which Fernando de Rojas controlled and unfolded his drama of paradox.

(1974: 471-2).

We made reference before to the contrast existing between two different monologues by Celestina, at the beginning of Acts IV and v, respectively: the former shows a doubtful bawd, who fears what may come over her if she fails to stand up to her promise; in contrast, the monologue in Act $\mathrm{v}$ shows a self-assured, triumphant Celestina who is happy about the result of one of her first errands in the work. The following is the way in which these monologues are conveyed by Mabbe:

Celestina: Now that I am all alone, I will, as I walke by my selfe, weigh and consider that which Sempronio feared, concerning my trauell in this businesse. For, those things wich are not well weighed, and considered, though sometimes they take good effect, yet commonly fall out ill. So that much speculation brings foorth good fruit; for although I dissembled with him, and did set a good face on the matter, it may be, that if my drift and intent should chance to be found out by Melibea's father, it would cost me little lesse then my life: (...)

(1631: 44, Act Iv, my italics)

Celestina: $O$ cruell incounter! $O$ daring and discreet attempt! $\mathrm{O}$ great and singular sufferance! $\mathrm{O}$ how neere had I beene to my death, if my much subtilty and cunning craft had not shifted in time the sailes of my suite! $O$ brauing menaces of a gallant Lady! $O$ angry and inraged Damsell! O thou Diuell whom I coniured! O how well hast thou kept thy word with me in all I that desired! (...). O good fortune, what a friend art thou to the valiant! what a foe to those that are fearefull! Nor by flying doth the Coward flye death. O how many failed of that which I haue effected! (...) For experience, and frequent warnings, make men Artists in their professions; and it must be such an old woman as I am, who at euere little Channel holds vp her coates, and treades the stretes with leysurely steps, that shall proue a Proficient in her trade.

(1631: 62, Act v, my italics). 
We can appreciate the same kind of tendencies as we have traced in Mabbe's translation techniques: thus, the main aspects of the message are reinforced by means of amplifications, geminations and further explicitations and explanations. This applies to the two monologues. It is certainly the one in Act V that replicates ironically the one in Act IV: if before Celestina seemed fearful, now we hear her satisfied about her success. In the monologue of Act $\mathrm{v}$, we can see that geminations apply particularly to Celestina's references to her own endeavours and the way she feels about them, as well as to Melibea's early reactions during their recent interview.

In a sense, foreshadowing may be approached as a particular, more specific case of dramatic irony, in so far as speakers are unaware of the ultimate consequences of their words and their actions. In fact, Sedgewick calls attention to the use of reminiscence within dramatic irony: "By an irony of reminiscence we are made to recall previous words we are made to recall words and acts which are mocked by words and acts of the present» (1960: 53).

The effects sought by irony may be even more intense if more than one form of irony merges in a certain context. As a matter of fact, it may be argued that the classification into the forms of irony that we have been following does not really lead to the establishment of clear-cut forms. Quite on the contrary, in a single context and even in one single utterance we may find the merging of different forms of irony. This is the case of the following example, where three different forms have merged, namely dramatic, tragic irony and foreshadowing:

Sempronio: No tiene otra tacha sino ser codiciosa; pero déjala barde sus paredes, que después bardará las nuestras o en mal punto nos conoció.

$$
\text { (ca.1502/2000: 145, Act VI). }
$$

Sempronio: It is her fault, I must confesse, but other Vice hath shee none, saue onely that shee is a little too couetous. But let her alone, and giue her leaue to prouide straw, first, for to thatch her owne walls, and to lay the ioyses first of her owne house, then afterwards shall she boord ours; else had it beene better for her shee had neuer knowne vs.

(1631: 67-68)

Here, we can see how the aspects that may be said to lie at the core of the message conveyed by Sempronio have been amplified by Mabbe, by using resources typical of colloquial speech, such as the use of proverbs. Besides, the speaker's expression of attitude has also been enhanced. In contrast, one of the aspects that has undergone fewer changes concerns precisely Sempronio's threat: even so, in Mabbe's text it is expressed 
from the standpoint that would have been adopted by Celestina, and also as if he had been trying to provide her with advice.

Sempronio's menace will sadly be accomplished, on the basis of Celestina's covetousness. But at this moment he cannot know for sure what her reaction will be like. What is more, a further level of dramatic as well as tragic irony will be that Celestina's death will also be the reason for his own - as well as Parmeno's_- perishing.

Dramatic irony may often reinforce the pathos of tragic irony, in so far as the speaker is unaware of the ultimate consequences of the mistake that she makes and which will inevitably bring forward her own destruction. In this sense, Celestina epitomises the figure of a tragic heroine, since the friendship between two of Calisto's servants, Pármeno and Sempronio, which she had formerly fostered, will never be closer than the very moment when they murder her.

We saw that twentieth-century criticism and studies of Celestina - apart from remarkable exceptions, such as Russell, Severin or Gilman - tended to emphasise its tragic aspects. Yet, comedy is also important in the work. Sometimes, it may relieve the tension between two more emotionally taxing scenes. Towards the end of the work, after the deaths of Celestina, Pármeno, Sempronio, and just previous to the final climatic scenes, Elicia and Areúsa plan revenge, and call for Centurio. It is ironic that Areusa - who one time was proud of her shrewdness, as well as her "honesty» - relies on him for their plot, after having charged him with having robbed her, no matter of how much she had helped him in the past, in Act XV. Just then, and to the reader's surprise, she had declared: "...de Calisto, Centurio me vengará» (ST: 292, Act XV). Now, in Act XVIII, we shall learn how he tries to get rid of the whole matter, after having boasted in front of the two women. Before that, he praises his sword, which allows him to proudly refer to some of his ancestors:

Centurio: Si mi espada dijese lo que hace, tiempo le faltaría para hablar. ¿Quién si no ella puebla los más cimenterios? (...) Veinte años ha que me da de comer. Por ella soy temido de hombres y querido de mujeres, sino de ti. Por ella le dieron Centurio por nombre a mi abuelo, y Centurio se llamó mi padre, y Centurio me llamo yo. Elicia: Pues, ¿qué hizo el espada por que ganó tu abuelo ese nombre? Dime, ¿por ventura fue por ella capitán de cien hombres?

Centurio: No, pero fue rufián de cien mujeres

(ca.1502/2000: 310-11, Act XviII, my italics).

Centurio: If my sword should but tell you the deedes it hath done, it would want time to vtter them. What does impeople Church-yards but it? (...) These twenty yeeres 
hath it found me food; by meanes of it am I feared of men, and beloued of women, onely your selfe excepted; for it, the name of Centurio was giuen to my Grandfather; for it, my father likewise was called Centurio, and so am I.

EliCIA: But I pray, tell me, what did your sword, that your Grandfather should gaine his name by it? Was hee by it made Captaine of a hundred men?

Centurio: No, hee was made by it Champion to an hundred women.

$$
\text { (1631: 181, my italics). }
$$

It is ironic that Centurio refers to his origins - which are the least honourable that might have been thought of- precisely before Areúsa, a character that had upheld the noblest and purest values of honour: she had defended a nobility of the heart, as opposed to the nobility of blood. Therefore, in the work, it is not just that some of the characters of the lowest social strata show respect towards those attitudes that their careless masters should have observed. Now, we confront a character, Centurio, who feels proud of his ancestors, which are but indeed base and unworthy. What is more, his boasting his own courage - which in fact he will lack - will soon after be contradicted in the restricted context of his monologue, once the two prostitutes have left: «Agora quiero pensar cómo me excusaré de lo prometido (...)» (ST: 313). Therefore, his innermost intentions are only revealed to external readers, who enjoy a much wider perspective than that of the two women.

Mabbe's translation has been fairly literal this time: thus, it has used the same kind of hyperboles that reveal the character's temperament. There is an amplification of the direct reference, in a mood of reproach, to Areusa, for not having corresponded him in his feelings. Even so, there is a significant departure from the original: if in the Spanish work, Centurio's grandfather was "rufián de cien mujeres», in the English version he has become "Champion to an hundred women". In a sense, this may be compared to the treatment of religious allusions, which has been studied by critics, as shown and illustrated above.

In commenting instances of comic irony, we have referred to the fact that Areúsa had defended the "nobility of the heart", as contrasted to the "nobility of the blood». Indeed, she is one of the characters belonging to those lowest, or even outcast groups of society, but who nevertheless will bring forward the most important moral lessons of the work. This is one of the aspects of the subversion of traditionally appreciated values, together with the masters' absolute neglect of them, and which is illustrated next: 
Areúsa: (...) Procure de ser cada uno bueno por sí, y no vaya a buscar en la nobleza de sus pasados la virtud.

(ST: 208, Act IX).

AREUSA: (...) Let euery man striue to be good of himselfe, and not goe searching for his vertue in the Noblenesse of his Ancestors.

(1631: 108, my italics).

Calisto: (...) $\bigcirc$ el dolor de mi deshonra. (...) ¡ $\bigcirc$ cruel juez, y qué mal pago me has dado del pan que de mi padre comiste! Tú eres público delincuente y mataste a los que son privados; (...) ¡ $\mathrm{O}$ cuán peligroso es seguir justa causa delante injusto juez!

(ST: 277-80, Act XIV)

Calisto: (...) Or whether it be the griefe, which I conceiue of my dishonour (...) $\bigcirc$ thou cruell ludge, what ill payment hast thou made mee of that my fathers bread, which so often thou hast eaten? (...) Thou thy selfe art a publike delinquent, and yet punishest those that were priuate offendors. (...) $O$ how hard a matter is it, to follow a iust cause before an vniust Iudge!

(1631: 156-157, my italics)

It is perhaps hard not to associate the allusion to "euery man» within the English dramatic tradition, in the otherwise literal translation of Areusa's words, which enhances the universal value that they are intended to have. In any case, the resoluteness of her words contrasts with those of Calisto's even though they have been produced in very different contexts. Likewise, Areusa's crying for universal values contrasts with Calisto's appeal for the concrete, and ultimately for his own selfish particular interest. In the English versions, the perceptual, subjective aspects of Calisto's words have been made explicit: "which I conceiue», and also the strong accusation he makes against the judge: «thy selfe». The same kind of adjectives as the Spanish original has been used, and the word order required by the English language enhances the contrast between «a publike delinquent» and "priuate offendors".

Finally, instances of a form of irony which contradicts the classical definition of it as «meaning the opposite or something different from what has been said" are also found. As noted above, this is a resource typical of the Spanish drama, and consists precisely in deceiving by telling the truth. It can be specially enjoyed by the external addressees, who are offered the possibility to grasp the whole significance, in contrast to the victim. In Celestina, some of the few instances that can be found have Elicia as a protagonist: one is the scene where Celestina reaches home with Sempronio 
and she is upstairs with another lover; in another, reproduced next, she makes another reference to her having lovers other than Calisto's servant:

Sempronio: (...) Pero todo lo doy por bien empleado, pues tal joya gané.

ELICIA: ¡Mucho piensas que me tienes ganada! Pues hágote cierto que no has tú vuelto la cabeza cuando está en casa otro que más quiero, más gracioso que tú, y aun que no anda buscando cómo me dar enojo.

(ca. 1502/2000: 211; Act IX, my italics)

Sempronio: (...) All which I hold well spent, and thinke my selfe happy in them, sithence they gained me so great and faire a lewell.

ELICIA: You doe well to perswade your selfe so: But howsoeuer you conceit you haue gained mee. I assure thee, thy backe is no sooner turn'd, but another is presently with me, whom I loue better then thee, and is a properer man then thou art, and one that will not goe vexing and angring mee, as thou dost. (...)

(1631: 110, my italics).

Significantly enough, Elicia starts her response to Sempronio by retaking his very same words, only to express her distance towards them and thus to show then her despise towards the servant. But she goes deeper into her cruelty, by telling him in the face that she happens to be another lover, and thus contradicting all sorts of expectations that he might have cherished, regardless of whether he becomes aware of this or not -as may be expected to be the case, because of his own folly and Celestina's subsequent intervention.

In Mabbe's translation, it is interesting to appreciate that what has been expanded concerns precisely Sempronio's attitude and blindness about what the situation happens to actually be: "... and thinke my selfe happy", as well as Elicia's intention to deceive him: "You doe well to perswade your selfe so". Besides, in the English version, she even takes the liberty to tell him that he is being deceived: "But howsoeuer you conceit you haue gained mee». Therefore, her cruelty is also emphasised.

\section{Captain Stevens's The Bawd of Madrid (1707)}

So far, this piece has not been studied in depth. Like Rastell's work, it stands for a genre departure from the original. It is written as a prose, narrative version, structured into nine chapters. This time, the story of Celestina is part of a collection of stories or translations from Spanish, dealing with picaros (rogues), bawds and the like: The Spanish Libertines. 
These narratives have a clear didactic purpose, as the author himself makes it manifest: "The design of them is not to Teach those vile Practices they contain, but rather to expose Vice and the base Contrivances of Scandalous Persons" (1707: A2). As a matter of fact, their purpose comes close to Horace's maxim docere et delectare. This is explicitly pointed at by the narrator: "They at once Delight and Instruct, leading the Reader (...) to reap the Advantage of the Information they give him, for the avoiding the danger of ill Courses and dishonourable Company» (1707: A2).

The works that are enclosed are the following versions of Spanish literary masterpieces, together with The Spanish Bawd: "The Country Jilt», as a version of La Pícara Justina; and also an English version of Estavanillo Gonzales or The Comical Scoundrel. (From "The Preface»). It is somehow curious to find that the author deliberately neglects the other two previous versions by Rastell and by Mabbe, as he claims the following: "To which is added a Play call'd An Evening's Adventures. All Four written by Eminent Spanish Authors, and now first English'd by Captain John Stevens» (1707: A2, my italics).

The most remarkable feature of Stevens' Celestina is the pre-eminent presence of an omniscient, heterodiegetic narrator, who judges every character and every action from above. As a result, even what has been conveyed with minute resemblance to the original may be done so in a completely different context, with the subsequent change in meaning. Besides, the author has carried out a selection of those passages which in his view deserve either being quoted at length, or being summarised with certain detail. In contrast, other different scenes and acts may just briefly be referred to.

Aspects like the ones just commented upon crucially affect the conveyance of such a heavily context-dependent resource as irony, to the extent that it may be lost or cancelled in an important number of the passages which admit an ironical reading in the original text. In this way, the narrator plays an important role in the way the text is to be interpreted: everything we perceive is done so through his lenses. Moreover, as an internal reader, he does not spare comments which show his attitude and feelings towards the characters. Therefore, characters or their actions do not reach the external addressee or reader in a neutral, objective way.

An important consequence of the former is that, on the one hand, in the original, external readers are still given certain freedom to reach their own conclusions. On the other hand, in Stevens' version, the narrator, who may be regarded as a reader of the source text, tends to offer his own interpretation which is imposed upon the external addressee. One of the possible ways in which this is done is by applying only the conclusion reached by the narrator himself, instead of offering the wider array of possible interpretations or possible readings that are offered in Rojas' work. 
Thus, before the external reader sees Celestina acting, the narrator has told the reader the following about her: «Here was Born, and here Liv'd the most Infamously Celestina, a Woman Basely Born, Vilely Educated, and of a Scandalous Wicked Life» (1707: 69). Then, the narrator himself becomes ironic about his own judgement of the old bawd. This, if in Chapter I he has made a description of Celestina that overflows with comments such as the one quoted above, then, at the beginning of Chapter II, the narrator aims to synthesise all that information. He does so then by saying: "These were the Perfections; these the Practices; and this the Life of Celestina» (1707: 73, my italics).

But there are further consequences: thus, not having access to the same context and therefore having entertained other assumptions than those of the original audience, English readers are likely to process very differently even such information about the old bawd that can be regarded as a translation from the original: thus, in the Tragicomedia, the first references that readers are provided with about Celestina will be found as early as the "Argumento" of the work, where she is described as a "mala y astuta mujer» (ST: 24). Then, Sempronio refers to her as «una vieja barbuda que se dice Celestina, hechicera, astuta, sagaz en cuantas maldades hay. (...) A las duras peñas promoverá y provocará a lujuria si quiere» (ST: 47). Calisto's reaction towards these words has diverse implications in the original text and in Stevens' version: thus, in Celestina the young lover is delighted about Sempronio's promises to bring the old bawd to him, but all information about his reaction is provided by his own words: «iPodríala yo hablar?» or "¿Y tardas?» (ST: 47-8). In Stevens" version, however, the ridiculous traits of the character are emphasised through the narrator's assessment: "Calisto was overjoy'd at the Proposal, and impatient to see her, promising Mountains if she could bring about his Design» (1707: 76, my italics).

An important aspect of this version is, therefore, the alternation of the dialogues as they are rendered in the original, - even though they may be received in very different contexts from the original, on account of the previous comments made by the narrator, on the one hand. On the other hand, the narrator interprets or summarises other dialogues. This results in diverse effects for irony, which range from its complete loss, if compared to the original, to the introduction of irony in passages where it was not present at all in the Spanish work.

However, perhaps the most important trait is that whereas in the original it is the reader who is invited to reach his own conclusions, as he has direct access to the participation of the different characters, in Stevens' version everything is mediated through the selection and interpretation of the narrator. As we have seen, in such different contexts, even those words that are literally translated may have new interpretations and shades of meaning. It has also been observed that many times it is the narrator who introduces the characters, usually before they start acting 
themselves in contrast not only to the original text, but also to the Interlude, where, following the characteristics of the genre, characters tend to introduce themselves. In the context of Stevens' work, this means that the external readers may judge and entertain their own assumptions and assessment of the characters, even before they turn up.

The former also has other implications, as regards the different kinds of irony to be found in the text, in contrast to those of the original Celestina: thus, the number of instances of dramatic irony has greatly diminished, as characters do not have such an important participation in the action. The same may be said about anticipatory irony and foreshadowing, which in many instances also contain an element of dramatic irony, in so far as the character cannot be possibly aware of the ultimate consequences of his words. Therefore, in many contexts in Stevens' work, these kinds of irony are cancelled or non-existent, if compared to the original.

Even though Stevens's work is formally different from the original text, we shall attempt, wherever possible, to analyse the same fragments of the text, for each variety of irony distinguished above. In that way, on the one hand, those fragments which have been conveyed in a dialogic form will allow us to compare two different translations of the same source text. On the other hand, in those fragments where it has been the narrator that has synthesised what has been going on, we shall analyse the ways in which the attitude he displays affects the conveyance and the reader's comprehension of irony.

Thus, as for the instances of foreshadowing and anticipatory irony that we have commented upon above, it is only the first that has been reflected: the action has been synthesised sometimes, and certain aspects have been omitted. This means, in the whole of the work, that the reader has not been provided with so much evidence regarding what may occur. In a sense, this can be explained on the basis of the existence of the omniscient narrator, who enjoys his feelings of superior knowledge not just over the characters, but also over the external reader. The one that has indeed been reflected stands out by the adoption of a colloquial register, with the introduction of popular English proverbs, which shows the writer's attempt to adapt the action to the English cultural environment. The images connected with sexual violence have been mitigated, even more than in Mabbe's version:

Parmeno: Shall I see you Home, Mother?

Celestina: That would be Robbing of Peter to Play Paul. Rest you Merry, I am an Old Woman, and need not fear to go alone in the Street.

$$
\text { (1707: 104; Chapter v). }
$$

The two monologues by Celestina, which opened up Acts IV and v, respectively, being the latter an instance of retrospective irony in connection 
with the former, also illustrate the changes undergone by this version, on account of the presence of the omniscient narrator. ${ }^{11}$ It is significant how the narrator's words really characterise him as a spokesperson of Celestina's innermost and private feelings. Many times, there are in retrospective irony - as well as in foreshadowing - aspects which are far beyond the intentions and certainly the control of the speaker. This provides the external reader with further satisfaction. But here, such messages are mediated through the heterodiegetic and omniscient narrator, so that the reader cannot but believe what the narrator says, as there is no further source of evidence.

Other forms of irony in which there may be further layers of significance beyond the character's intention have to do with dramatic and tragic irony. Even though they may be used in texts for different purposes, they may also coalesce in similar contexts, so that their effects are reciprocally reinforced. Thus, in the following fragment the narrator refers to Calisto's meeting with Celestina, which is witnessed by his two servants. The interests of each of them cannot be more different:

11.- On account of their length, especially the one that corresponds to Celestina's monologue in Act IV, we reproduce next in this footnote the two passages that convey, through the omniscient narrator, what used to be the two monologues by the old bawd, at the beginning of Act IV and $\mathrm{v}$ of Celestina, respectively:

"Having made all the Necessary Dispositions she sets forward, yet not without some Apprehensions of what might happen; reflecting by the way on the Caution Sempronio had given her, and that all Actions of Concern and Hazard ought to be maturely weigh'd. For should Fortune prove so unkind as to Discover her Designs, it might cost no less than her Life, to attempt the Debauching of a Virgin of that Rank and Quality; and should they prove more Merciful, yet the least Punishment to be expected was Tossing in a Blanket, or a severe Flogging at the Carts-Tail. To go on, seem'd to have somewhat of Rashness; and to return without attempting anything, favour'd too much of Cowardice. Cudges, Lashes, Pillories, and all sorts of Vexations, seem'd to appear in proceeding; and in desisting, there was the Shame of Sempronio's Scoffs and Reproaches, and above all the dread of Calisto's Indignation, who would easily see into her Frauds; and, being Powerful, Execute some severe Revenge for having been so foully impos'd on. Courage, and the Prospect of future Gain, prevail'd, and drew her on, hoping still, that at the worst, Calisto might protect her against Pleberio. And observing that since her sitting out upon this Errand no unhappy Omens had fallen in the way, but rather all things seem'd to Prognosticate and Forebode Success; as, that of Four Men she met, Two were Cuckolds; the first Words she heard in the Street were morous; she never stumbled as other times; nor was tir'd, or encumber'd with her Coats; all Persons Saluted, and no Dogs Bark'd at her; no unlucky Birds, as Crows or Jack-Daws, had appear'd; and what was best of all, she spy'd Lucretia, Melibea's Maid, and Cousin to Elicia, at the Door» (1707: 82, my italics, Chapter III).

"Having secur'd her Intelligence, she hasted Home to carry the News, Meditating on the Dangers she had escap'd, the Arts she had us'd, the readiness of the Infernal Imps to assist her at a Pinch, and the advantage she conceiv'd her Charms and Filthy Drugs had been to her» 1707: 91, Chapter III). 
His Servants, Sempronio and Parmeno, who were present, and heard all the Discourse, sometimes Laughed at his Folly, sometimes grew weary of his Impertinent Tediousness. One while they Admir'd the Crafty Insinuations of the Old Woman; and then again Curs'd her Greedy Temper, which extoll'd every Particular to make a merit, and claim a fresh Reward. But that which most incens'd them was, that still she represented the Poverty of her Habit, and at last openly begg'd a Gown, Petticoat and Veil, which Calisto immediately order'd should be given her. Nor was their Concern to see their Masters Wealth lavish'd, but that she should beg those things which were not capable of being divided, whereas they had propos'd to make Calisto their Common Prey, and to share the Booty equally among them all. Night came on to put an end to their Discourse; Celestina departed, and Pármeno with her, by his Masters Order.

(1707: 92, Chapter III).

This fragment corresponds to Calisto's interview with Celestina after the old bawd's first encounter with Melibea, when the Celestina makes him acquainted with the success of her enterprise. The servants, however, are quite careless about this and are only interested in the bawd's reluctance to share the booty with them.

In Stevens' version, on account of the narrator's omniscience, the attitudes and ultimate purposes of each character are explicitly made manifest, so that there is little to be interpreted or inferred by the external reader. In a sense, as a result, the narrator acts as a reader of the source text and supplies the target-text reader with just one possible interpretation, thus narrowing down the scope of the original.

As noted above, humour is important in Celestina. For instance some characters are best seen as comic figures. This is the case of Centurio, despite the role that he had been intended to play in the two prostitutes' design. In Celestina, he explicitly manifests how he wants to wash his hands of the whole affair of the vengeance, and in fact, little will he have anything to do with Calisto's tragic end. In Stevens' version, the whole explanation of the name and lineage of the character - which in Celestina he proudly refers to Areúsa - is synthesised by the narrator:

The Ruffian would scarce hear her out; telling her, $\mathrm{He}$ knew all the Intrigue; which way it was manag'd; and how far she was Concern'd; but that he was engag'd that Night, yet he would lay aside all Business to Oblige her; for his Sword was us'd to Fatten the Churchyards; to Enrich the Surgeons; and to find Work for the Ar- 
mourers; That he had Liv'd by it Twenty Years; ever Fear'd by Men, and Belov'd by the Women; and from it his Grandfather was call'd Centurio, as having been Bully to an Hundred Whores.

(1707: 154).

In this way, the narrator really comes to interpret the two characters, but focusing especially on the ruffian s words, so that Areúsa has a much more restricted, passive role. Centurio's actions come therefore as a list, as an enumeration, as if his role in the action were going to be much more important than what it will actually be.

As is well known, an important aspect of the message communicated by Rojas in his work concerns the subversion of traditionally upheld values, and it is here that Areúsa plays an interesting role, in the sense that she, being a prostitute, and therefore, an outcast, points at moral standards that would be universally accepted. Her attitude will contrast against the sole concern about appearances of Calisto's, who would belong to the upper social strata:

Areusa: (...) Let every one mend one, and not seek for Nobility from the Vertues of their Ancestors.

(1707: 112).

He [Calisto] Rail'd at the Judges who had precipitated the Execution; looking upon it as done in Contempt of his Person, and a great Diminution of his Honour; and above all, he dreaded being disappointed of his Assignation that Night; the two Criminals being the only Persons Privy to it, and in whom alone he thought he could confide, and put all his Trust.

$$
\text { (1707: 143, my italics). }
$$

Although it is not always easy to assess the reasons why Stevens has opted for the direct style, in contrast to what has been reported by the narrator, it is perhaps significant that Areusa's words, which contain one of the most universal messages of the work, have been conveyed in direct style. In contrast, Calisto's fully coward attitude is not only reflected by the omniscient narrator, but also judged and assessed as a consequence by the latter. As has occurred with many of the passages which have been conveyed by the narrator, he reaches his own conclusions, and the external reader does not have any access to the character's actual words. 


\section{Conclusions}

The present study has set out to analyse the earliest reception of the Spanish work Celestina, by Fernando de Rojas, in the Anglo-Saxon cultural environment. Such reception has been contextualised in the following aspects of the literary panorama in Britain at the time: the importance of translations in Elizabethan England and immediately subsequent periods; the intrinsic novelty and contributions of a heterogeneous version such as Rastell's Calisto and Melebea, in so far as it is one of the very first works in British drama that we find "real life», with well-rounded characters as the protagonists of the story.

We have reached the following conclusions. As regards the impact of the forms of irony that have been distinguished in Celestina in each of the versions under study, the situation is heterogeneous. On the whole, the three works illustrate the differences in the interpretation of irony that may result from changes in the context. This may be due to the constraints imposed by the conventions of the genre of the target text: thus, in the Interlude, no traces either of tragic irony or foreshadowing has been spotted, on account of the happy ending of the target text. As for Stevens' version, many of the forms of irony that do not depend on the characters' will have simply disappeared, on account of the tight constraints imposed by its omniscient narrator. As for Mabbe's version, even though it is presented as a translation that follows the structure and conventions of the original text, this time differences in the perception of irony may arise as a result of certain ideological changes that are introduced, if compared to the original: thus, both religious allusions and blasphemous language have been omitted or else rephrased, so that the work could avoid censorship.

The overall importance of the three works has been assessed against their context and their historical significance. They made accessible to the English audience an important work of the Spanish literature. Besides, they stand as the only three extant versions of Celestina that have been preserved from 1525 to 1707 until more than two centuries later. 


\section{Works Cited}

Act to Restrain Abuses of Players (1606). <http:/www.enotes.com/ocsencyclopedia/act-restrain-abuses-players $>$ (Last accessed: 08 July, 2010).

Alcina Franch, Juan, ed. 1983. Fernando de Rojas: "La Celestina». Barcelona: Laia.

Allen, H. Warner, ed. 1923. Celestina or the Tragi-Comedy of Calisto and Melibea. Translated from the Spanish by James Mabbe, anno 1631. Also An Interlude of Calisto and Melebea. Printed by John Rastell, circa 1530. With an Introduction on the Picaresque Novel and Appendices. London: Routledge \& Sons.

ARDIlA, John G. 1998. «Una traducción "políticamente correcta"»: Celestina en la Inglaterra puritana». Celestinesca 22.2: 33-48.

Axton, Richard, ed. 1979. Three Rastell Plays: Four Elements, Calisto and Melebea, Gentleness and Nobility. Cambridge: D.S. Brewer, Rowman and Littlefield.

Ayllón, Cándido 1984. La perspectiva irónica de Fernando de Rojas. Madrid: Ediciones José Porrúa Turanzas.

Bataillon, Marcel 1961. "La Celestine» selon Fernando de Rojas. Paris: Didier. Brault, Gerard J. 1960. "English translations of the Celestina in the sixteenth century». Hispanic Review vol. 28. 4: 301-12.

Brioschi, F. and C. di Girolamo 1988 (1984). Introducción al estudio de la literatura. Barcelona: Ariel.

Brooke, Tucker and Matthias A. Shaaber 1967 (1948). A Literary History of England. Volume II: The Renaissance. London: Routledge and Kegan Paul. BusH, Peter trans. 2009. Celestina. Dublin: Dedalus Press.

CANET, José Luis 2008. "La Celestina en la 'contienda' intelectual y universitaria de principios del s. XVI». Celestinesca 32: 85-107.

Capellanus, Andreas (Andrés el Capellán) 2005 (ca.1174-1186). Libro del Amor Cortés. Ed. Pedro Rodríguez Santidrián. Madrid: Alianza.

Celaya, M ${ }^{a}$ Luz and Pedro Guardia 1992. "The Spanish Bawd: traducción y mitologización». Livius 2: 139-48.

Conen, J. M. trans. 1964. Rojas. The Spanish Bawd. La Celestina. Being the Tragi-Comedy of Calisto and Melibea. Harmondsworth: Penguin.

Deyermond, Alan, ed. 1961. The Petrarchan Sources of La Celestina. London: Oxford University Press.

—, ed. 1980. Historia y Crítica de la Literatura Española: La Edad Media. Barcelona: Crítica.

—, 1987. Historia de la literatura española: La Edad Media. Barcelona: Ariel. Fitzmaurice-Kelly, James ed. 1884. Celestina or the Tragicke-Comedy of Calisto and Melibea Englished from the Spanish of Fernando de Rojas by James Mabbe, Anno 1631. London: David Nutt in the Strand.

Forster, Edward M. 1983 (1927). Aspects of the Novel. London: Macmillan. 
Fraker, Charles F. 1990. "Celestina». Genre and Rhetoric. London: Tamesis Books Ltd.

Geritz, Albert J. 1979. "Calisto and Melebea: A Bibliography». Celestinesca 3.2: $45-50$.

- 1980. "Calisto and Melebea (ca. 1530)». Celestinesca 4.1: 17-29.

Gilman, Stephen 1974 (1956). The Art of "La Celestina». The University of Wisconsin Press.

- 1980. «La voz de Fernando de Rojas en el monólogo de Pleberio», in Historia y Crítica de la Literatura Española: La Edad Media. Ed. A. Deyermond. Barcelona: Crítica: 517-20.

GlickSBerg, Charles Irving 1969. The Ironic Vision in Modern Literature. The Hague: Martinus Nijhoff.

Guardia Massó, Pedro 1971. James Mabbe, Eminente Hispanista y Traductor Oxoniense del Siglo XVII. Barcelona: Universidad. Unpublished Ph. Dissertation.

- 1998. "La Comedia de Calisto y Melibea de Fernando de Rojas (Burgos, 1499). The Spanish Bawd represented in Celestina (London, 1631)». Picaresca española en traducción inglesa (sS. XVI y XVII). Antología y estudios. Ed. Javier Sánchez Escribano. Zaragoza: Universidad de Zaragoza. 51-67.

GuRZA, Esperanza 1977. Lectura existencialista de "La Celestina". Madrid: Gredos.

Hartnoll, Phyllis, trans. 1959. Celestina. London: Dent \& Sons.

HATim, Basil and Ian Mason 1990. Discourse and the Translator. London and New York: Longman.

HimmelblaU, Jack 1968. "A Further Contribution to the Ironic Vision in the Tragicomedia». Romance Notes 9: 312-13.

Houck, Helen Phipps 1939. "Mabbe's Paganization of the Celestina». PMLA 54: 422-31.

HuerTaS, Miguel 2008. "La Celestina de Nin-Culmell: un estreno largamente deseado». La Celestina. Tragicomedia Musical en tres Actos. Ópera xxi. Catálogo General de Publicaciones Oficiales: 7-11.

Jones, John 1968 (1962). On Aristotle and Greek Tragedy. London: Chatto and Windus Ltd.

Jones, Richard F. 1953. The Triumph of the English Language. California: Stanford.

KisH, Kathleen V. 1989. "Celestina: estímulo multisecular». Actas del X Congreso de la Asociación Internacional de Hispanistas. Ed. Antonio Vilanova. Barcelona: PPU: 249-54.

- 1996. "The wines of Celestina and the omnibibulous H. Warner Allen». Nunca fue pena mayor: Estudios de literatura española en homenaje a Brian Dutton. Eds. Ana Menéndez Collera and Victoriano Roncero López. Cuenca: Universidad de Castilla-La Mancha: 359-66.

- 2009. "Celestina as Chameleon: The Early Translations». Celestinesca 33: 87-98. 
LACARRA, Ma Eugenia 1989. «La parodia de la ficción sentimental en La Celestina». Celestinesca 13.1: 11-15.

Lida De Malkiel, Ma Rosa 1961. Two Spanish Masterpieces: "The Book of Good Love» and "The Celestina». Urbana: University of Illinois Press.

- 1970 (1962). La originalidad artística de "La Celestina». Buenos Aires: Eudeba.

Lobera, Francisco J. et al., eds. 2000. Fernando de Rojas (y «antiguo autor»). La Celestina. Tragicomedia de Calisto y Melibea. Barcelona: Crítica.

Martin, June Hall 1972. Love's Fools: Aucassin, Troilus, Calisto and the Parody of the Courtly Lover. London: Tamesis Books Ltd.

Martínez Lacalle, Guadalupe ed. 1972. Fernando de Rojas. Celestine or the Tragick-Comedie of Calisto and Melibea. Translated by James Mabbe. London: Tamesis Books.

Menéndez Pelayo, Marcelino ed. 1947. "La Celestina». Buenos Aires: Austral, Espasa-Calpe.

MoRini, Massimiliano 2006. Tudor Translation in Theory and Practice. Aldershot: Ashgate.

MuRILlo Murillo, Ana Ma 1992. "Love and chastity in two early English versions of La Celestina». Proceedings of the II Conference of SEDERI. Ed. Santiago González Fernández-Corugedo. Oviedo: Universidad: 193-203.

- 1994. "Cultural transfer in different literary contexts: the case of $L a$ Celestina». In Transvases Culturales: Literatura, Cine, Traducción. Eds. Federico Eguíluz et al. Vitoria: UPV/ EHU: 351-58.

Navarro García, José Luis 1981. "John Rastell y su "Comedia de Calisto y Melibea»». Cauce 4: 43-75.

PHILIPS, Katherine Kayser 1974. "Ironic Foreshadowing in La Celestina». Kentucky Romance Quarterly 21: 469-82.

Purcell, H.D. 1967. "The Celestina and the Interlude of Calisto and Melebea». Bulletin of Hispanic Studies 44: 1-15.

Randall, Dale B. J. 1998 (1963). The Golden Tapestry. A Critical Survey of Non-Chivalric Spanish Fiction in English Translation. (1543-1657). Durham, North Carolina: UMI- Duke University Press.

Rank, Jerry R. 1988. Review Fernando de Rojas. Celestina. Ed. with intro. and notes by Dorothy Sherman Severin. Celestinesca 12.1: 59-61.

Rastell, J. 1979 (1525). "Calisto and Melebea». Three Rastell Plays: Four Elements, Calisto and Melibea, Gentleness and Nobility. London: D.S. Brewer, Rowman and Littlefield. 69-96

Rodríguez Puértolas, Julio 1972. "Nueva aproximación a La Celestina». De la Edad Media a la edad conflictiva: estudios de literatura española. Madrid: Gredos. 217-42.

- 1976. Literatura, historia, alienación. Barcelona: Labor.

RosenbaCh, A.S.W. 1903. "The Influence of The Celestina in the Early English Drama». Jahrbuch der Deutschen Shakespeare-Gesellschaft xxxIx: 43-61. 
RusSELL, Peter E. 1953a. «English Seventeenth-Century Interpretations of Spanish Literature». Atlante I: 65-77.

— 1953b. "A Stuart Hispanist: James Mabbe». BHS 30: 75-84.

- ed. 1991. La Celestina. Comedia o tragicomedia de Calisto y Melibea. Madrid: Clásicos Castalia.

San Pedro, Diego de 1971 (1492). "Cárcel de Amor». Ed. Keith Whinnom. Obras Completas II. Madrid: Castalia.

Sánchez Escribano, F. Javier 1998. Picaresca española en traducción inglesa (sS. XVI y XVII): antología y estudios. Zaragoza: Librería General.

SAYERS PeDEn, Margaret trans. and Roberto González Echevarría ed. 2009. Celestina. Yale UP.

SCHelLING, F. E. 1923. Foreign Influences in Elizabethan Plays. New York: Macmillan.

Sedgewick, G.G. 1960. Of Irony: Especially in Drama. London: Oxford UP. Severin, Dorothy Sherman ed. 1969. Fernando de Rojas: La Celestina. Madrid: Alianza Editorial.

- 1978-9. «Humour in La Celestina». Romance Philology 32: 274-91.

- ed. and trans. 1987. The Spanish Bawd. Celestina. With the Translation of James Mabbe (1631). Warminster: Aris and Phillips. Hispanic Classics. Mediaeval.

- 1989. Tragicomedy and Novelistic Discourse. Cambridge: CUP.

— ed. 1994. Fernando de Rojas: La Celestina. Madrid: Cátedra Letras Hispánicas.

Simpson, Lesley B. trans. 1955. The Celestina. A Novel in Dialogue. In 16 Acts. Berkeley and Los Ángeles: University of California Press.

Singleton, Mack Hendricks trans. 1958. Celestina. A Play in Twenty-One Acts Attributed to Fernando de Rojas. Madison: University of Wisconsin Press.

Snow, Joseph 1985. 'Celestina' by Fernando de Rojas:An Annotated Bibliography of World Interest, 1930-1985. Madison WI: HSMS.

- 1996. "Retórica e ironía en La Celestina». Ed. and coord. Antonio Rubio Flores. Retórica medieval: ¡continuidad o ruptura? Granada: Universidad. 45-60.

- 1997. "Hacia una historia de la recepción de Celestina: 1499-1822». Celestinesca 21: 115-73.

- and Arno Gimber 2007. «Richard Strauss, Stefan Zweig, Joseph Gregor and the Story of the Celestina Opera that Almost Was, with a Bibliographical Appendix of Celestina Operas in the Twentieth Century». Celestinesca 31: 133-165.

SteVens, John 1707. "The Bawd of Madrid». In: The Spanish Libertines: The Spanish Jilt, The Bawd of Madrid, Estevanillo Gonzales and An Evenings Intrigue. London: Printed for S. Bunchley at the Publishing Office in Bearbinder Lane. pp. A2-160. 
UnGer, Gustav 1956. Anglo-Spanish Relations in Tudor Literature. Berne: Schweizer. Anglistische Arbeiten.

Venuti, Lawrence 1995. Translator's Invisibility: A History of Translation. London and New York: Routledge.

WALSH, Andrew S. 2000. "La belleza actual de Celestina: la adaptación teatral de Luis García Montero». Celestinesca 24: 171-80.

Whinnom, Keith 1980. "La Celestina, The Celestina, and L2 interference in L1». Celestinesca 4.2: 19-21.

Woolsey, Wallace trans. (1969). The Spanish Bawd. New York: Las Américas Publishing Co.

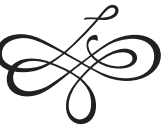




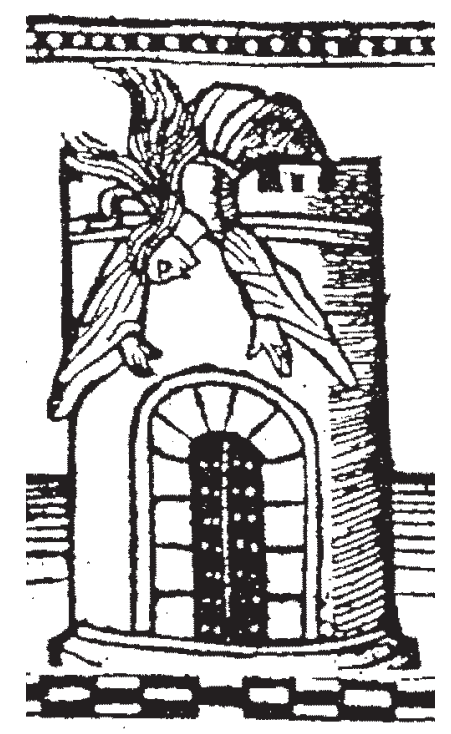




\section{Ruiz Moneva, Ma Ángeles, "Main Aspects of the Reception and Conveyance of Irony in the Earliest English Versions of Celestina», Celestinesca, 34 (2010), pp. 99-142.}

\section{RESUMEN}

La Celestina (Rojas, 1499/ ca.1502) fue pronto traducida al inglés, en formas literarias muy diferentes, que han de entenderse como "recreaciones» más que traducciones, estrictamente hablando (Murillo, 1994, 1992): la versión de Rastell (1525), escrita como un interludio, y The Bawd of Madrid, de John Stevens (1707), como una obra narrativa. Únicamente Celestine, de Mabbe (1631), es formalmente similar a la obra de Rojas. La crítica siempre ha considerado la ironía como un elemento esencial del mensaje expresado por Rojas. De forma general, cabrá esperar que los cambios en el género tanto de la obra de Rastell como de la de Stevens influyan en la manera en la que se transmite la ironía. Por otra parte, aunque la versión de Mabbe sigue la misma estructura y los mismos temas del original, algunos de sus aspectos esenciales subyacerán en ciertas interpretaciones de la ironía peculiares.

PALABRAS ClAVE: Celestina, traducciones en la Inglaterra isabelina, ironía, cambios de género textual, factores que afectan la percepción, transmisión y traducción de la ironía.

\section{ABSTRACT}

Celestina (Rojas, 1499/ ca.1502) was shortly after translated into English in the Elizabethan period, in very different literary forms, which would be best approached as «re-creations», rather than translations proper (Murillo 1994, 1992): Rastell's version (1525), written in the form of an interlude, and Captain Stevens' The Bawd of Madrid (1707), as a narrative piece. Only Mabbe's Celestine (1631) is formally similar to Rojas's work. Irony has always been acknowledged by critics as an essential element of the message conveyed by Rojas. On the whole, the genre shifts that Rastell's and Stevens' works underwent may be expected to influence the way irony is conveyed. On the other hand, although Mabbe's version follows the main structure and themes of the original, some essential features of this version lie at the core of some peculiar interpretations of irony.

KEY WORDS: Celestina, translations in Elizabethan England, irony, genre shifts, factors affecting the perception, transmission and translation of irony. 